PontIFícIA UNIVERSIDADE CATÓLICA dO RIO DE JANEIRO

Marca própria em um varejo de doces e biscoitos

O impacto na intenção de compras dos consumidores

Bruna Rodrigues Duarte

Trabalho de Conclusão de Curso

Centro de CIÊnCIAS SOCIAIS - CCS

DEPARTAMENTO DE ADMINISTRAÇÃo

Graduação em Administração de Empresas 


\section{Uso da marca própria em um varejo de doces e biscoitos O impacto na intenção de compras dos consumidores}

Trabalho de Conclusão de Curso

Trabalho de Conclusão de Curso, apresentado ao programa de graduação em Administração da PUC-Rio como requisito parcial para a obtenção do titulo de graduação em Administração.

Orientador(a): Daniel Kamlot

Rio de Janeiro, junho de 2019. 


\section{Resumo}

Duarte, Bruna. Uso da marca própria em um varejo de doces e biscoitos: o impacto na intenção de compras dos consumidores. Rio de Janeiro, 2019. Número de páginas 46 p. Trabalho de Conclusão de Curso Departamento de Administração. Pontifícia Universidade Católica do Rio de Janeiro.

O estudo teve como objetivo principal medir a intenção de compras do consumidor em relação a um produto de marca própria.

A fim de medir a intenção de compras, foram mostrados quatro produtos, dois de marca de fabricante e dois de marca própria, para os respondentes precifica-los e em uma escala, demostrar qual a probabilidade de comprá-los.

Os resultados foram favoráveis e as intenções de compras superaram a média.

Também foi analisada a relação do consumidor com produtos de marca própria no geral, e por fim, foram avaliados quesitos relacionados ao varejo estudado.

\section{Palavras-chave}

Marca própria, varejo, intenção de compras.

\section{Abstract}

Duarte, Bruna. Sobrenome, Nome do autor. Título e subtítulo em inglês. Rio de Janeiro, 2019. Número de páginas 46 p. Trabalho de Conclusão de Curso - Departamento de Administração. Pontifícia Universidade Católica do Rio de Janeiro.

The main objective of this study was to measure the consumer's intention to purchase in private label product.

In order to measure the consumer's intention, four products from manufacturer's brand and other two private label products for the public to price them and, in a scale, demonstrate the purchase probability.

The results were favorable and the intentions of purchase overcame the average.

It was algo analyzed the relation of the consumer with private label in general, and finally, points related to the retail were evaluated.

Key-words

Private label, retailing, purchase intention. 


\section{Sumário}

1 O tema e o problema de estudo 1

1.1. Introdução ao tema e ao problema do estudo 1

1.2. Objetivo do estudo 2

1.3. Objetivos intermediários do estudo 2

1.4. Delimitação e foco do estudo 3

1.5. Justificativa e relevância do estudo 3

2 Revisão de literatura 4

2.1. Varejo 4

2.2. Marca 6

2.2.1. Marca Própria 8

2.3. Gestão da Marca 11

2.4. Decisão de Compra 13

3 Métodos e procedimentos de coleta e de análise de dados do estudo 17

$\begin{array}{ll}3.1 . & \text { Tipos de Pesquisa } \\ & 17\end{array}$

3.2. Fontes de informação selecionadas para coleta de dados no estudo17

3.3. Procedimentos e instrumentos de coleta de dados utilizados no $\begin{array}{ll}\text { estudo } & 18\end{array}$

3.4. Formas de tratamento e análise dos dados coletados para o estudo18

$\begin{array}{ll}\text { 3.5. Limitações do Estudo } & 19\end{array}$

$\begin{array}{ll}4 \text { A Empresa } & 20\end{array}$

5 Apresentação e análise dos resultados 24

5.1. Descrição da amostra 24

5.2. Análise da intenção de compra do consumidor perante marca própria30

5.3. Análise Marca Própria 34

5.4. Análise Empresa Casa do Biscoito 38 
6 Conclusões e recomendações para novos estudos

\section{Lista de figuras}

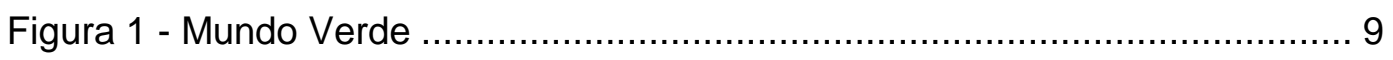

Figura 2 - Linha Taeq - Grupo Pão de Açúcar ............................................. 10

Figura 3 - Conjunto de consideração de marcas gerenciável ........................... 15

Figura 4 - Casa do Biscoito - Segunda loja (bairro Freguesia) ......................... 21

Figura 5 - Figura 5 - Casa do Biscoito - Ano do registro ............................... 22

Figura 6 - Casa do Biscoito - Mudança de layout ........................................ 22

Figura 7 - Casa do Biscoito - Modernização da fachada................................ 23

Figura 8 - Panettone/Chocottone Bauducco ................................................. 31

Figura 9 - Panettone/Chocottone Casa do Biscoito ...................................... 32

Figura 10 - Biscoito salgadinho Torcida ................................................... 33

Figura 11 - Biscoito salgadinho Casa do Biscoito .......................................... 33

\section{Lista de Tabelas}

Tabela 1 - Consumidores x Fabricantes ................................................... 6

Tabela 2 - Média de Qualidade .............................................................. 35

Tabela 3 - Renda x Quantas vezes o respondente compra marca própria ........ 38

Tabela 4 - Média dos itens avaliados ........................................................ 41

Tabela 5 - Com quem mora x Quantas vezes compra na Casa do Biscoito ...... 42 
Tabela 6 - Compram quaisquer produtos na Casa do Biscoito x Compram produtos de marca própria da Casa do Biscoito 42

\section{Lista de Gráficos}

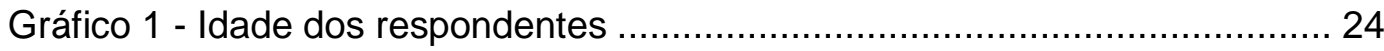

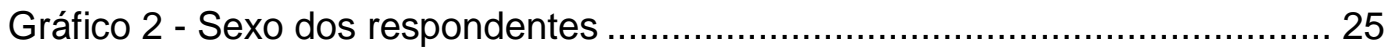

Gráfico 3 - Escolaridade dos respondentes ............................................... 26

Gráfico 4 - Renda dos respondentes ......................................................... 27

Gráfico 5 - Com quem o respondente mora atualmente ................................. 28

Gráfico 6 - Onde reside os respondentes .................................................. 29

Gráfico 7 - Profissão dos respondentes..................................................... 30

Gráfico 8 - Frequência que os respondentes compram produtos de marca própria 35

Gráfico 9 - Média de qualidade x quantidade de vezes por semana que o respondente compra marca própria ..................................................... 36

Gráfico 10 - Fatores que influenciam o respondente a adquirir marca própria... 36

Gráfico 11 - Como o respondente costuma chegar pela primeira vez a um produto de marca própria .................................................................. 37

Gráfico 12 - Respondentes sobre os produtos de marca própria da Casa do Biscoito. 39

Gráfico 13 - Frequência que o responde costuma comprar quaisquer produtos na Casa do Biscoito. 40

Gráfico 14 - Grau de satisfação sobre itens avaliados da Casa do Biscoito 41 


\section{0 tema e o problema de estudo}

\subsection{Introdução ao tema e ao problema do estudo}

O setor varejista tem grande força no Brasil, pois considerando o varejo restrito, a SBVC (Sociedade Brasileira de Varejo e Consumo) relata que o mesmo representou 20,25\% do PIB nacional em 2017 (retirando automóveis e materiais de construção), e de acordo com o PMC (Pesquisa Mensal de Comércio, divulgado pelo IBGE), o volume acumulado de vendas de 2018, cresceu 2,3\% em relação ao acumulado de 2017, o setor de produtos alimentícios foi um dos que exerceu uma grande contribuição para o resultado

Marca própria é uma estratégia criada pelos varejistas e atacadistas a fim de se obter vantagem competitiva, que, segundo Barney (2011), é a capacidade de agregar um valor econômico maior que dos concorrentes.

Segundo Parente (2007) marcas próprias, são marcas concebidas e vendidas com exclusividade por varejistas ou atacadistas, e as marcas fabricantes são marcas de domínio de um fabricante, podendo ser vendidas por diferentes varejistas e atacadistas.

Em um estudo feito pela Nielsen em 2016, publicado em 2017 a marca própria no Brasil não tem conseguido alcançar os mesmos rendimentos apenas com o fato dos preços serem competitivos, o verdadeiro propulsor tem sido a diferenciação.

Foram anunciadas no país 58 novas marcas próprias, dessas 51 foram de varejistas regionais e 2.190 produtos subdivididos em 148 categorias. (NIELSEN, 2017)

Os produtos básicos com marca própria como papel higiênico, feijão, açúcar, arroz, têm sido os mais escolhidos pelos consumidores brasileiros, em 2016 cresceram mais do que as marcas de fabricantes, $13,4 \%$ e $9,6 \%$ respectivamente. (NIELSEN,2017) 
Segundo a Nielsen (2017), esse crescimento se deve ao fato de que os brasileiros, em meio à crise, acreditam que produtos de categoria básica de marca própria são aceitáveis para atender suas necessidades.

Já as marcas com foco em produtos premium, ou seja, produtos diferenciados, cresceram 3,5 vezes mais do que as outras marcas. (NIELSEN, 2017)

Ainda de acordo com Nielsen (2017), mesmo crescendo, a evolução da marca própria no Brasil tem um dos piores desempenhos quando comparada à de outros países do continente Sul-Americano, sendo de 7,9\%, sendo assim, estando longe também da média global de 16,1\%.

É retratado também pelo estudo que alguns dos fatores responsáveis pelo não-crescimento da marca própria no Brasil são: a centralização desse setor nos grandes varejistas, a complexidade da logística juntamente com a dificuldade de encontrar fornecedores eficientes; e por fim, a falta de gestão da marca, pois para uma boa gestão da marca própria, não se pode limitar somente ao produto estar disponível nas gôndolas e a preços mais baixos, questões como definição estratégica e interação com o consumidor também devem ser analisadas. (NIELSEN, 2017)

Como citado acima, sendo a falta de gestão estratégica e a comunicação ao consumidor quesitos que impedem o seu crescimento, se faz necessário investigar: Quais os impactos que a marca própria tem na intenção de compra do consumidor?

\subsection{Objetivo do estudo}

Como apontado no item 1.1, um dos motivos que dificultam o crescimento da marca própria no ramo varejista é a não interação com o consumidor, então o presente artigo tem como objetivo analisar a influência da marca própria na intenção de compra do consumidor varejista de doces e biscoitos.

\subsection{Objetivos intermediários do estudo}

Com a finalidade de atingir o objetivo final, o presente trabalho pretende alcançar os seguintes objetivos intermediários:

$\checkmark$ Verificar com que regularidade o consumidor compra produtos de marca própria e o que pensam em relação à qualidade desses 
produtos, para conferir qual associação os consumidores fazem sobre os mesmos

$\checkmark$ Identificar fatores que influenciam o consumo da marca própria, e quais elementos induzem os consumidores á compra-los a fim de gerenciar estratégias para captar os clientes potenciais

$\checkmark$ Avaliar alguns atributos importantes do varejo estudado neste trabalho como preço, atendimento, qualidade, variedade dos produtos, facilidade de encontrar os produtos na loja, localização das lojas para então identificar pontos fortes a serem explorados e pontos fracos a serem aprimorados

\subsection{Delimitação e foco do estudo}

Este estudo está focado em analisar os consumidores da marca Casa do Biscoito, são eles residentes do Rio de Janeiro e consumidores de panetone e biscoito salgadinho.

Foi feita a escolha desses dois produtos para obtermos dois extremos, pois o panetone é um produto que está concorrendo diretamente com marcas conhecidas e carros-chefes da loja e o biscoito salgadinho é um produto que não concorre com marcas de grandes nomes.

\subsection{Justificativa e relevância do estudo}

Os resultados aqui encontrados serão proveitosos e contribuirão para a área de marketing da Casa do Biscoito, pois estarão detectando os impactos que a estratégia de fornecer marca própria no varejo possui frente aos seus consumidores.

Além disso, poderá gerar informações que auxiliará o varejista em questão em suas decisões, pois o mesmo poderá identificar possíveis meios de potencialização de suas vendas de produtos próprios.

Por fim, também será válido para os varejistas do mesmo ramo e que adotam tal estratégia 


\section{Revisão de literatura}

Neste capítulo, será retratado o fundamento teórico que sustentará a análise realizada, o qual é composto por conceitos e estudos já realizados e relativos ao tema de forma relevante para este estudo.

Sua estrutura é composta por quatro partes: a primeira parte tratará sobre o contexto do varejo, e com isso ambientar o cenário estudado. Na segunda parte serão detalhados os conteúdos de marcas e marcas próprias, trazendo seus conceitos, objetivos estratégicos, histórico de marca própria e exemplos. $\mathrm{Na}$ terceira parte, gestão da marca, com o objetivo de compreender melhor este processo e sua importância para fortalecer uma marca, discorrer sobre brand equity e as etapas para um gerenciamento de marcas eficiente. Por fim, na quarta parte, o comportamento de compra será apresentado, a fim de fundamentar as atitudes dos consumidores.

\subsection{Varejo}

O ambiente estudado no presente artigo é inserido no ramo do varejo, com isso, se faz necessário apresentá-lo.

Segundo Levy e Weitz (2000), varejo é um dos maiores setores da economia mundial e o define como uma soma de atividades de negócios que adiciona valor a produtos e serviços, vendidos a consumidores para seu uso pessoal e familiar.

O varejista é o negociante que liga fabricantes a consumidores no canal de distribuição (Levy e Weitz, 2000).

Além disso, Levy e Weitz (2000) afirmam também que há quatro funções exercidas pelos varejistas:

- A primeira é a de oferecer um sortimento de produtos e serviços aos clientes, e então possibilitar que seus consumidores possam ter opções de escolha em um único local.

- A segunda é a função de dividir lotes grandes em pequenas quantidades, ou seja, oferecem os produtos em quantidades menores, para consumidores individuais. 
- A terceira é manter estoque, esta função se dá como uma das atividades principais, pois é fundamental que os produtos estejam disponíveis quando os consumidores quiserem, e então não ser preciso que o próprio cliente tenha que manter grandes quantidades em casa.

- Por último, fornecer serviços, serviços estes que facilitam a compra e o uso dos produtos pelos clientes, fornecendo crédito, exibindo o produto de maneira adequada e ainda ter funcionários disponíveis para oferecer ajuda. Desse modo, agregando valor aos produtos e serviços.

Finalizando a visão de Levy e Weitz (2000) sobre varejo, é valido citar os elementos do composto do varejo que são: localização; diversidade de mercadorias; preço; publicidade e promoção; design de loja e exposição; atendimento ao cliente e venda pessoal, e então os autores relatam que quatro desses elementos, nos embasam para classificar o tipo de varejista são eles: tipo de mercadoria vendida, variedade/sortimento, nível de atendimento ao cliente e o preço da mercadoria. No presente trabalho, estaremos abordando sobre um varejista de alimentos.

Para Parente (2007), varejo é definido como todos os procedimentos que envolvem o processo de venda de produtos e serviços para atender à necessidade pessoal do consumidor final. E menciona que o varejista é qualquer entidade cujo exercício principal é a venda de produtos e serviços para o consumidor final.

Parente (2007) deixa claro o fato de ser atividade principal relacionada ao consumidor final, pois há fabricantes e atacadistas que vendem também diretamente para o consumidor, porém não são considerados varejo, visto que esta não é a sua principal fonte de receita, deixando clara a diferença entre eles.

Essa ambientação é importante, em primeiro lugar, para a compreensão da ligação que ambos têm, pois, como citado anteriormente, é fundamental o sortimento de mercadorias para um varejista, a competitividade de preço, a agregação de valor ao cliente, entre outros. E esses são diferenciais que a marca própria agrega, pois, a mesma é bastante adotada por conseguir atender múltiplas necessidades tanto do varejista quanto do cliente e será detalhado a seguir.

Além disso, outro objetivo deste tópico foi o de investigar os conceitos de varejista e atacadista a fim de diferenciar ambos. 


\subsection{Marca}

Cabe discorrer sobre a definição de marca, a fim de compreender o fundamento antes de detalhar o conceito de marca própria.

De acordo com Aaker (2003), marca é um nome diferenciado e/ou símbolo que tem como objetivo identificar os bens ou serviços de um vendedor e assim, distinguir de seus concorrentes, principalmente os que oferecem produtos semelhantes, com isso, indicando ao consumidor a origem do produto e preservando o consumidor e o fabricante.

Tavares (2008), relata que a marca possui três funções, a primeira é a de mostrar o que ela e o produto a ela relacionado é, ou seja, seu nome, seu símbolo; a segunda é a sua finalidade, para o que serve; e por fim, os resultados, isto é, diferenciá-la frente a seus concorrentes a fim de ser a preferida entre os consumidores.

Na concepção de Keller e Machado (2006), marca é um produto que possui valores e, com isso, particulariza-o frente a seus concorrentes que atendem a mesma necessidade; essas diferenças podem ser materiais, ligadas ao funcionamento da marca, ou podem ser ligadas ao que ela representa, ou seja, diferenças intangíveis.

Keller e Machado (2006) listam ainda os papéis importantes que as marcas desempenham, para os consumidores (indivíduos ou organizações) e fabricantes, conforme Tabela 1:

Tabela 1 - Consumidores x Fabricantes

\begin{tabular}{|c|c|}
\hline Consumidores & Fabricantes \\
\hline Identificação da origem do produto & $\begin{array}{l}\text { Identificação para simplificar } \\
\text { rastreamento }\end{array}$ \\
\hline $\begin{array}{l}\text { Atribuição de responsabilidade ao } \\
\text { fabricante }\end{array}$ & $\begin{array}{l}\text { Proteção legal para aspectos } \\
\text { exclusivos }\end{array}$ \\
\hline Redução de riscos & $\begin{array}{l}\text { Indicativo de qualidade para } \\
\text { consumidores }\end{array}$ \\
\hline Simplificação do custo de busca & $\begin{array}{l}\text { Meio para criar associações } \\
\text { exclusivas }\end{array}$ \\
\hline Vínculo com o fabricante do produto & Fonte de vantagem competitiva \\
\hline Elementos simbólicos & Ativo para retornos financeiros \\
\hline Indicativo de Qualidade & \\
\hline
\end{tabular}

Aprofundando a importância da marca, Keller e Machado (2006) citam três categorias de benefícios e atributos associados ao produto, são elas: (a) bens de 
pesquisa, em que se avaliam características visuais como tamanho, cor, peso; (b) bens de experiência, cujos atributos são percebidos após testá-los, como durabilidade, facilidade e qualidade; por fim, (c) bens de credibilidade, cujo atributo é pouco verificado, como em cobertura de seguros.

Outra quesito citado é a redução dos riscos que as marcas oferecem, sendo eles: risco funcional, que é o risco de não operar de acordo com a expectativa criada; risco físico, quando há uma ameaça ao usuário, seja ao bemestar físico ou à saúde; risco financeiro, quando o valor pago não compensa; risco social, que é o risco do produto gerar certo constrangimento; risco psicológico, isto é, o risco do usuário ter a saúde mental afetada; risco de tempo, que é o risco do usuário não se satisfazer com o produto e com isso, perder seu tempo para encontro um outro. (KELLER e MACHADO, 2006)

Finalizando a visão de Keller e Machado (2006), os autores ressaltam também a importância das marcas para os varejistas e distribuidores, pois a mesma gera predileção dos consumidores a uma loja, com isso gerando expectativas quanto às ofertas, e dessa forma contribuindo para a criação de imagem e do posicionamento da loja.

Oliveira (2008) cita também que o fundamental para uma marca é a conquista da lealdade de seus clientes, sendo assim, quanto maior essa lealdade, menor será a instabilidade frente a uma execução de seu concorrente.

O autor cita a pirâmide da lealdade, na qual o primeiro estágio relata o cliente não-leal à marca, ou seja, o que é sensível a mudança de preço e não leva a marca em consideração; o segundo estágio é o do cliente satisfeito, sempre consome daquela marca e não tem motivo para mudar; em terceiro, o cliente satisfeito, porém com receio dos custos de mudança; em seguida, o cliente que gosta da marca e a considera; e por último, o cliente que é comprometido com a marca - para chegar a esse estágio, é necessário um trabalho a longo prazo. (OLIVEIRA, 2008)

Outra visão é a dos autores Tybout e Calkins (2018), que relata que o significado de marca é dividido em três categorias que o profissional de marketing precisa gerenciar, são elas: imagem da marca, essência da marca e cenário competitivo.

Sobre imagem da marca, os autores mencionam que é a concretização da proposta do profissional de marketing, como é visto de forma externa. Sobre essência da marca, Tybout e Calkins (2018), afirmam que é a interpretação por parte do cliente perante a proposta do profissional de marketing. Por fim, cenário 
competitivo, que, conforme os autores, é o cenário com os produtos, imagens e informações do mercado construído pelos consumidores em um ambiente material e simbólico. (TYBOUT e CALKINS, 2018)

\subsubsection{Marca Própria}

Dado isso, Parente (2007) aponta a questão da importância do equilíbrio entre marcas próprias e de fabricante, pois assim como uma grande parcela de produtos próprios melhora as margens de lucro e estimula a fidelidade dos clientes, em contrapartida, alguns acreditam que, quando a oferta de produtos próprios ultrapassa um percentual apropriado, o consumidor pode considerar a variedade oferecida como limitada.

Parente (2007) menciona também alguns objetivos que o varejista pretende atingir quando opta por implementar a estratégia de se obter marca própria no seu sortimento de mercadorias, são eles:

- Fortalecer a sua imagem;

- Desenvolver a fidelidade do consumidor através de sua linha exclusiva;

- Ganhar maior poder de barganha frente aos fornecedores;

- Oferecer a seus clientes mais alternativas e diminuir a vulnerabilidade diante de oferta dos concorrentes;

- Aumentar a força competitiva, pois estará ampliando a variedade e melhorando a imagem do preço e produtos com a relação custo/benefício;

- Atender melhor às necessidades dos clientes

- Aumentar seu poder de decisão de gerenciamento de categorias.

Segundo Pereira (2001), o preço mais baixo desses produtos, é relacionado ao fato de que os varejistas os compram por preços menores e a custos mais enxutos, e completa que, o menor preço não é ligado a redução da qualidade.

Outra visão sobre o conceito, segundo a ABMAPRO (Associação Brasileira de Marcas Próprias e Terceirização), é de que marca própria é todo serviço ou produto, fabricado, beneficiado, processado, embalado para uma organização que detém o controle e distribuição da marca, a qual pode levar, ou não, o nome desta.

Alguns exemplos de varejistas que adotam a marca própria utilizando o próprio nome são: Supermercado Carrefour, Mundo Verde, entre outros. 
Conforme Oliveira (2008), as vantagens são: potencializar as vendas, consolidar a imagem da marca, anunciar a empresa e com isso obter a fidelidade dos clientes, custo mais baixo de comunicação; já as desvantagens são: necessidade de manter uma alta administração da qualidade devido a essa associação, caso haja uma fusão ou aquisição com empresas concorrentes que também possuam marca, poderá haver conflito em relação ao nome da marca que anteriormente carregava o nome da empresa, uma marca com nome a parte, neste caso, evitaria certos conflitos.

\section{Figura 1 - Mundo Verde}

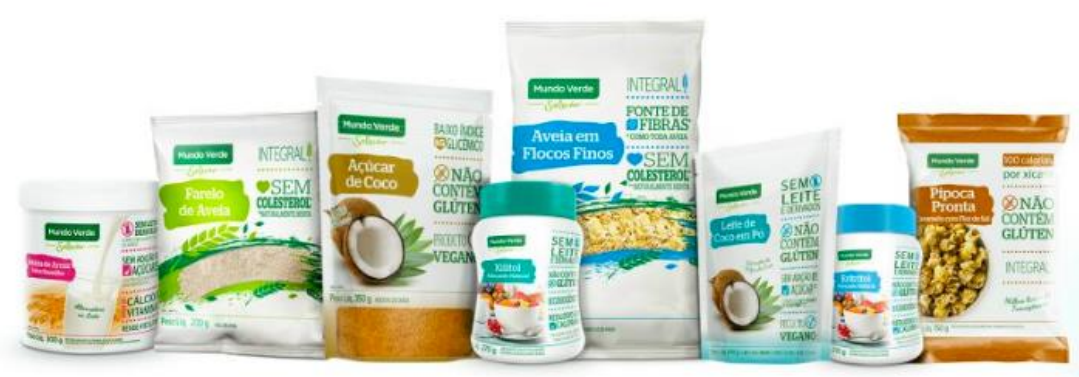

Fonte: Site Meio e Mensagem

Varejistas que optam por não associar o nome do estabelecimento com sua marca própria são exemplificados em: Supermercados Pão de Açúcar, Lojas Americanas, entre outros.

Oliveira (2008) traz vantagens e desvantagens para os que não associam o nome também, as vantagens são: flexibilidade ao erguer a marca sem se preocupar com ligação com o nome da empresa, podendo assim crescer até mesmo fora da sua área de venda e também conservar o nome da empresa; as desvantagens são: processos mais caros e árduos. 
Figura 2 - Linha Taeq - Grupo Pão de Açúcar

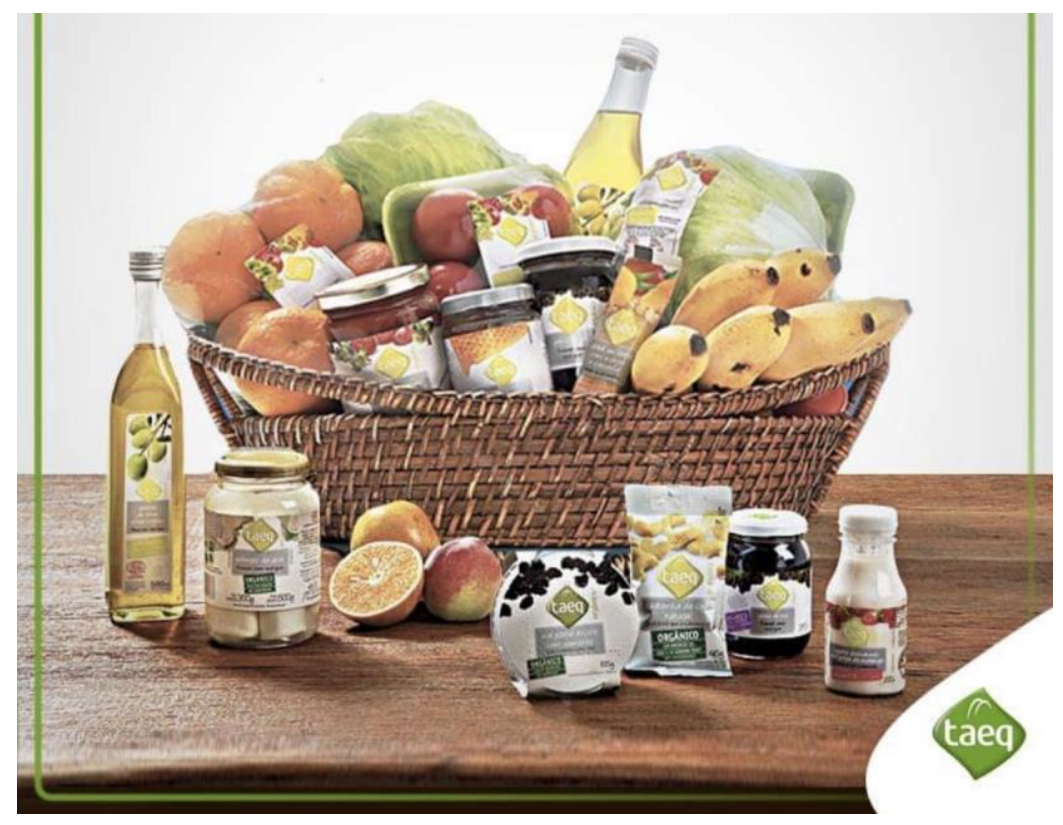

Fonte: Facebook Taeq

Com o objetivo de entender sua trajetória e como a marca própria chegou ao que é hoje, é pertinente retratar de forma sucinta seu histórico.

Segundo a ABMAPRO (Associação Brasileira de Marcas Próprias e Terceirização), a marca própria surgiu nos anos 50 na França, em seguida chegou na Inglaterra na década de 60 e então foi se estendendo pelos demais países. No Brasil surgiu nos anos 70 , e a princípio era vinculada a imagem de baixa qualidade, pois em sua primeira geração foi chamada de produtos genéricos, por não possuírem marca e serem comercializados pelo nome da categoria do produto.

A mesma passou por mais três gerações, nos anos 80 surgiu uma segunda geração, agora obtendo marca, porém, sem muita preocupação com qualidade. A partir dos anos 90, foi se concretizando e se expandindo pelo país como uma forma de se obter competitividade no varejo, entrando assim na terceira geração. Por último, em 2004, nasceu a quarta geração, chamada também de geração de valor, segundo ABMAPRO (Associação Brasileira de Marcas Próprias e Terceirização).

Sendo assim, ao finalizar este tópico, concluímos que a geração atual de marcas próprias é voltada para gerar valor à empresa, se preza a qualidade e tem o objetivo de concorrer com marcas fabricantes, com isso melhorar sua competitividade, desenvolver fidelidade e credibilidade, entre outros objetivos já 
mencionados. O varejista estudado neste arquivo optou por adotar o nome da própria empresa em seu produto.

\subsection{Gestão da Marca}

Conforme citado no item 1.1, a falta de gestão da marca é um dos fatores dominantes que impedem o crescimento da marca própria no mercado brasileiro, sendo então de suma importância desenvolver este tópico.

Ao discursar sobre gerenciamento de marca, é fundamental mencionar o Brand Equity, que segundo Aaker (2003), é um conjunto de ativos e passivos que se somam ou se subtraem do valor proporcionado pela marca. Os passivos e ativos em que o Brand Equity se fundamentam vão variar de acordo com cada ocasião. Porém, para facilitar, o mesmo é agrupado em cinco categorias:

- Lealdade à marca, que engloba:

- Custos de Marketing reduzidos

- Alavancagem comercial

- Atração de novos consumidores

- Tempo para responder às ameaças dos concorrentes

- Conhecimento do nome, que engloba:

- Apoio de ligações para outras associações

- Marca familiar

- Sinal de comprometimento

- Marca a ser considerada

- Qualidade percebida, que engloba:

- Razão de compra

- Diferenciação

- Preço

- Interesse no canal de distribuição

- Extensões

- Associações à marca em acréscimo à qualidade percebida, que englobam:

- Criar atitudes e sentimentos positivos

- Ajudar a interpretar fatos e passar mensagens e conceitos

- Diferenciação

- Outros ativos do proprietário da marca, como patentes, marcas registradas relações com os canais de distribuição, etc.

- Vantagem competitiva 
Além do mais, também é mencionado por Aaker (2003), que o Brand Equity cria valor tanto para o consumidor como para a empresa.

Para os consumidores, por meio do aumento da interpretação/processamento de informação, do aumento da confiança e da satisfação de uso; e para a empresa, por meio do aumento da eficiência/eficácia do marketing, da lealdade, dos preços/margens, das extensões da marca, do incremento com o Trade e da vantagem competitiva. (AAKER, 2003)

Outro ponto de vista importante de mencionar é o conceito de brandy equity fundamentado no cliente (CBBE - Customer-based brand equity), que segundo Keller e Machado (2006), é uma visão que aborda a concepção do cliente, seja ele pessoa física ou organização, pois é fundamental entender a atender os desejos e expectativas dos consumidores.

O modelo CBBE alega que a força da marca está nas experiências vividas pelo cliente em relação a ela, ou seja, em tudo aquilo que foi ouvido, sentido, aprendido e visto. (KELLER e MACHADO, 2006)

Keller e Machado (2006) também descrevem três elementos-chave que são; resposta diferenciada, conhecimento de marca e reação do consumidor a programas de marketing. O CBBE depende de distinções nas respostas do cliente, pois do contrário, o produto será classificado como produto de baixo valor agregado ou versão genérica, e neste caso, o preço seria o único diferencial da concorrência. Essas diferenças são efeitos do conhecimento sobre a marca. Uma das maneiras de fazer esta avaliação é através de teste cego.

A gestão estratégica de marcas possui como meta a melhoria progressiva da entrega da promessa da marca, que vai desde a definição até o contato com o público, se trata de um processo estruturado, consistente e integrado. (TOMIYA, 2010, apud NIELSEN e SÁ, 2012).

Os autores mencionam o método Brand and Image Strategy, que se trata de uma estratégia com etapas consecutivas, lineares e circulares. São etapas consequentes uma da outra e que quando se termina um ciclo, o outro é iniciado imediatamente. Este é um processo contínuo e sem fim, pois deve ir de acordo com as mudanças do mercado e do comportamento do consumidor e auxiliar na decisão estratégica da empresa, de acordo com Nielsen e Sá (2012).

A seguir serão apresentadas de forma breve as etapas deste modelo, com base nos autores Nielsen e Sá (2012):

- Raio X da marca: Esta etapa é definida por se aprofundar na empresa e na marca, conhecer a cultura da empresa e seus stakeholders, por meio de pesquisas de percepção e de marca, comportamento do 
público interno e externo, conversas com os envolvidos, a fim de entender a atual situação em que a marca está inserida. Por fim, esta etapa deverá ser fechada com a definição dos objetivos da empresa e seus acionistas.

- Estratégia e Posicionamento da Marca: Nesta se traçam as estratégias a partir de seus objetivos, é a etapa em que a marca define seu posicionamento perante seus stakeholders.

- Identidade da Marca: Identidade visual e verbal da marca, ambas expressam por meio de palavras e lingual o que a marca pretende (Keller e Machado (2007) apud Nielsen e Sá, 2012)

- Implementação: Implementar a marca é levá-la aos pontos de contato e potenciais públicos, porém os autores ressaltam que não é uma tarefa fácil devido à grande quantidade de pontos de contatos que se pode ter, com isso é preciso um planejamento de comunicação com base na segunda etapa, posicionamento da marca. Segundo Feldwick (2003 apud Nielsen e Sá, 2012) fornecer informações sobre a marca para torná-la conhecida, criando padrões distintos de associações e significados para torná-la mais atraente é o objetivo desta etapa.

- Avaliação e Gestão da Marca: Por fim, a ultima etapa é a de avaliar e gerenciar, com isso analisar todas as etapas anteriores para então realizar as manutenções necessárias e o aperfeiçoamento das ações de estruturação da marca.

\subsection{Decisão de Compra}

Conhecer sobre comportamento do consumidor é de extrema importância para as tomadas de decisões dos administradores. O enfoque em decisões de compra é fundamental para compreender os impactos que a marca própria tem na intenção de compras do consumidor e que serão analisados neste trabalho.

Engel, Blackwell e Miniard (2000) definem como comportamento do consumidor as atividades diretamente envolvidas em obter, consumir e dispor de produtos e serviços, incluindo os processos decisórios que antecedem e sucedem estas ações.

Peter e Olson (2009) apontam que comportamento do consumidor compreende os pensamentos e os sentimentos que são experimentados pelos consumidores e seus atos em um processo de compra, englobando igualmente 
os fatores influenciadores do ambiente, como palpites escutados, aparência do produto, dados e propagandas, isto é, trata-se de um conceito dinâmico, envolvendo interações e trocas.

Peter e Olson (2009) relatam também que por se tratar de um estudo que envolve relação entre sentimentos, ações e pensamentos entre consumidores e ambientes, é preciso entender também o significado que os produtos e as marcas têm para os consumidores, com isso, analisar o que é preciso ser feito para estimular a compra e o consumo.

"A estratégia de varejo eficaz satisfaz as necessidades do cliente melhor que as estratégias de concorrência. Portanto, compreender as necessidades do cliente e seu comportamento de compra é fator importante para tomar-se uma decisão de varejo eficaz." (LEVY e WEITZ, 2000, p.119)

Parente (2007) menciona o modelo dos cinco estágios do processo de compra:

- Reconhecimento do problema: Nesse primeiro estágio do processo é quando ocorre o estímulo inicial do processo de compra, em que se identifica o problema ou se sente uma necessidade, pode ser concebido de maneira física, de maneira mental e no plano espiritual.

- Busca pela informação: Após a etapa acima, o consumidor vai atrás de informações. Há uma conexão entre o produto e o tipo de comportamento de compra. Por isso este depende do valor do produto, da sua importância e da experiência já vivida pelo consumidor.

- Análise das alternativas pré-compra: Nessa parte, após as informações obtidas na etapa anterior, o consumidor compara e averigua as opções disponíveis para a decisão de compra. O autor fornece exemplos de atributos que são usados para a avaliação como mix de produtos, preço, a apresentação, a promoção, o pessoal de atendimento e o ponto de localização, o conjunto analisado varia entre os diferentes clientes e tipos de estabelecimentos varejistas. O intuito do varejista é não ser só uma loja considerada e sim, preferida.

- Decisão de Compra: Após passar pelas fases acima, o consumidor toma as seguintes decisões: comprar ou não, onde e o que comprar. A consequência está ligada ao estilo de compra 
do consumidor. Todo produto comprado é categorizado como compra planeja, não planejada ou por impulso.

- Avaliação pós-compra: São os processos que acontecem depois da compra.

Peter e Olson (2009) apresentam como um conjunto de consideração de marcas gerenciável pode se construir durante o estágio três, alternativas précompra, conforme Figura 3.

Figura 3 - Conjunto de consideração de marcas gerenciável

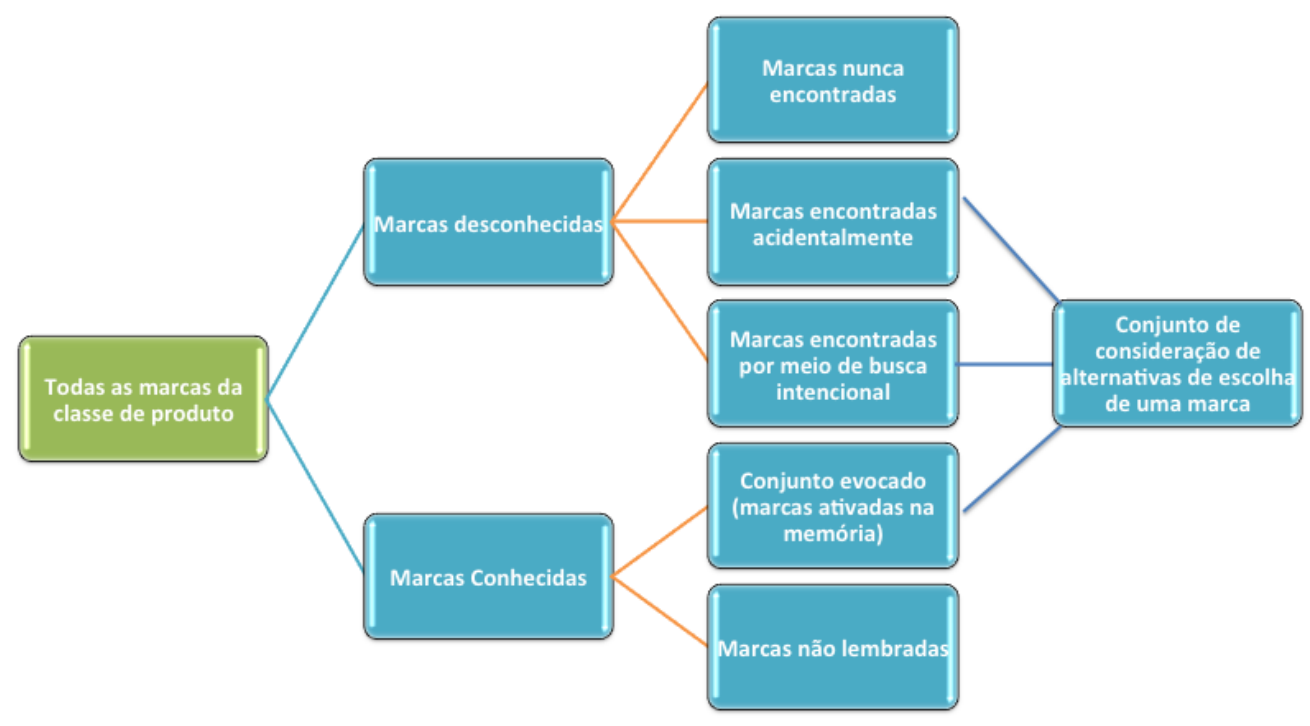

Fonte: Peter e Olson (2009)

Engel, Blackwell e Miniard (2000), apresentam três categorias de variáveis que formam a tomada de decisão:

- Diferenças individuais, que englobam os recursos do consumidor, tais como financeiros, tempo, capacidade de informação, conhecimento e atitudes sobre a marca, motivação no processo decisório, personalidades e estilo de vida

- Influências ambientais, são fatores como cultura, classe social em que o indivíduo é inserido, influência daqueles com quem se associa estreitamente, influência familiar e fatores situacionais

- Processos psicológicos, informação em processamento, aprendizagem, mudanças de atitudes. 
É necessário entender as razões ocultas às opções dos consumidores para poder satisfazê-los, quanto maior o conhecimento, maior a oportunidade de se antecipar e moldar o comportamento dos consumidores, de acordo com Sobral e Peci (2008).

Conforme Sobral e Peci (2008), a decisão de compra não é racional, pois a escolha é interferida por diversos fatores. Os autores citam também que os consumidores podem desempenhar um ou vários papéis nesse processo decisório. Tais papéis englobam o iniciador, que apresenta e/ou sugere a compra; o influenciador, que dá opinião e influencia no processo; o decisor, indivíduo que decide o que/quando/onde/quando e como comprar; o comprador, quem efetiva a compra; e o usuário, quem consome o produto/serviço.

Compreender estes comportamentos é significativo para o varejista pois o mesmo precisa definir quem e como atingir, captar e manter um relacionamento. 


\section{Métodos e procedimentos de coleta e de análise de dados do estudo}

Nesta etapa, será explicitada a metodologia de pesquisa aplicada a fim de alcançar o objetivo deste trabalho.

\subsection{Tipos de Pesquisa}

Segundo Vergara (2000), existem diversas taxionomias de tipos de pesquisa, porém a autora sugere a que é dividida em dois critérios, quanto aos fins e quanto aos meios.

Dentre as opções apresentadas por Vergara (2000), quanto aos fins, esta foi uma pesquisa descritiva, isto é, uma pesquisa que demonstra características de uma população ou fenômeno estabelecido, podendo também demonstrar correlações entre variáveis e determinar sua natureza. A mesma serve de suporte para explicar os fenômenos que descreve, porém não tem tal como dever tal explicação.

Quanto aos meios, se trata de uma pesquisa bibliográfica e de campo, bibliográfica pois é fundamentada em material acessível ao público como livros, internet, revistas e jornais; e de pesquisa de campo pois há um estudo no local cujo fenômeno acontece ou aconteceu, ou que possuiu elementos para explicalo, nesta pesquisa entrevistas, questionários, testes e observações podem ser englobados (VERGARA, 2000).

\subsection{Fontes de informação selecionadas para coleta de dados no estudo}

A amostra engloba moradores do Rio de Janeiro e de Minas Gerais, visto que são os lugares onde há Casa do Biscoito.

O questionário foi passado impresso em duas lojas, uma localizada no bairro da Penha, zona norte do Rio de Janeiro, e a outra localizada no bairro da Freguesia, zona oeste do Rio de Janeiro, com a finalidade de coletar amostras presenciais com os consumidores de diferentes localidades do Rio de Janeiro. 
Também foi passado o questionário online através de redes sociais, incluindo a página de Facebook da empresa Casa do Biscoito, com o intuito de captar uma amostra mais ampla de clientes

\subsection{Procedimentos e instrumentos de coleta de dados utilizados no estudo}

Para coletar os dados utilizados neste estudo, foi elaborado um questionário composto de 22 perguntas, sendo elas 4 abertas e 18 fechadas.

O questionário foi segmentado em 4 etapas:

- A primeira etapa, teve o propósito de analisar a intenção de compra do consumir, comparando dois produtos marca fabricante a dois produtos de marca própria da empresa estudada e medindo sua probabilidade de compra através da escala Juster. (4 perguntas abertas e 4 perguntas fechadas)

- Na segunda etapa, o objetivo foi o de coletar informações a respeito de marca própria. (4 perguntas fechadas)

- Na terceira etapa, o intuito foi o de avaliar quesitos relacionados a empresa estudada. (3 perguntas fechadas)

- Por fim, na quarta etapa, a finalidade era a de colher dados sobre o respondente. (7 perguntas fechadas)

A pesquisa foi distribuída pela internet, através da plataforma de pesquisa online Qualtrics, por meio de redes sociais como Facebook, Instagram e Whatsapp e distribuídas de forma impressa também para coletar respostas presenciais.

A pesquisa foi passada do dia 21 a 30 de maio de 2019 .

\subsection{Formas de tratamento e análise dos dados coletados para o estudo}

Se trata de uma pesquisa quantitativa, e a partir dos dados coletados foi usada estatística descritiva para analisá-los.

Nas perguntas abertas, foi utilizada média aritmética para chegar no preço médio dos respondentes.

Para analisar a intenção de compras, foi aplicada a escala de Juster.

Foi fundamental para a análise também cruzar os dados a fim de se obter relações entre eles como: renda e quantas vezes se compra marca própria por 
mês; média de qualidade com quantas vezes compra produtos de marca própria por mês; entre outros, e então estabelecer um padrão.

\subsection{Limitações do Estudo}

Este estudo possui alguns limitadores como:

O respondente pode se sentir constrangido de expor sua opinião real, sendo solicitado a resposta na própria loja.

O respondente pode não saber de fato o que é marca própria e, ainda assim, responder, enviesando os resultados. 


\section{A Empresa}

A empresa estudada neste trabalho, é a Casa do Biscoito, sendo assim, afim de ambientá-la, cabe apresentar a história da marca.

As informações a seguir, foram obtidas através de uma entrevista no dia 1 de junho de 2019, com o presidente da rede Casa do Biscoito, Rodrigo Morais Duarte (presidente biênio 2018/2019).

Trata-se de uma empresa varejista de biscoitos, balas e doces em geral, composta por aproximadamente 110 lojas, situadas no Rio de Janeiro (capital e demais) e em alguns municípios de Minas Gerais como, Belo Horizonte, Juiz de Fora, Cataguases, Muriaé, entre outros.

Seus sócios fundadores, são 3 irmãos, do interior de Minas Gerais que vieram para o Rio de Janeiro com o intuito de melhorar suas vidas.

O primeiro contato que tiveram com o comércio foi no começo dos anos 90, no Ceasa-RJ, onde tinham um atacado de doces, chamado Duarte Doces, posteriormente, aproximadamente em 98, conseguiram ter sua própria loja no Mercadão de Madureira e então, saíram do Ceasa-RJ e se estabilizaram no Mercadão.

Paralelamente com a mudança para o Mercadão de Madureira, abriram sua primeira loja de varejo em Cataguases, município de Minas Gerais, vizinho da sua terra natal, com o nome Casa do Biscoito, com o intuito de ser uma loja teste.

Nos anos 2000, ocorreu um incêndio no Mercadão de Madureira, o fogo devastou todas as lojas, o que resultou no prejuízo de diversos comerciantes, incluindo o prejuízo dos irmãos.

O dinheiro do seguro, não foi o suficiente para pagar a dívida das mercadorias perdidas, porém, mesmo após o acontecido, decidiram se reerguer no mesmo ramo, com isso, conseguiram crédito com os fornecedores e a renegociação da dívida, que com o passar do tempo foi quitada.

Reabriram seu atacado ainda no bairro de Madureira, numa rua próxima a do Mercadão, o intuito era o de aguardar a reestruturação do Mercadão para então eles voltarem, porém perceberam que demoraria mais que o previsto e a loja no novo local não estava tendo resultados satisfatórios. 
Foi então, nesse momento que tiveram a ideia de trazer o modelo de loja do varejo, que possuíam em Minas, para o Rio de Janeiro.

A primeira loja Casa do Biscoito do Rio de Janeiro, foi inaugurada no final dos anos 2000, e se localizava no bairro do Méier, a segunda no bairro da Freguesia e assim por diante.

Em 2004, eram um total de 20 lojas, neste ano foi fundada a RECAB Rede Casa do Biscoito, e foi o ano que a mesma foi registrada, seu aniversário é contado a partir desta data.

Neste ano também foi criado o primeiro padrão, com layout, slogan e interior padronizado, figura 5.

Em 2008 ultrapassou as 100 lojas e tem como objetivo crescer cada vez mais.

Em 2013, houve mudança no layout, devido as inúmeras lojas concorrentes que surgiram com o layout parecido, então criaram a fachada "Casa do Biscoito - a original", e em 2014, houve a modernização desta fachada., conforme Figuras 6 e 7.

Figura 4 - Casa do Biscoito - Segunda loja (bairro Freguesia)

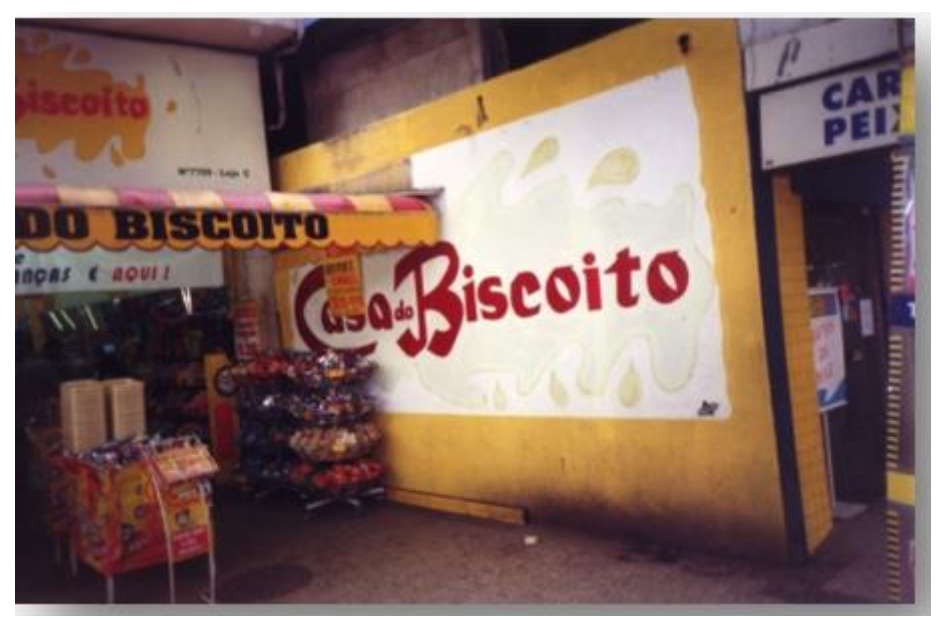

Fonte: Arquivos internos Casa do Biscoito (2000) 
Figura 5 - Figura 5 - Casa do Biscoito - Ano do registro

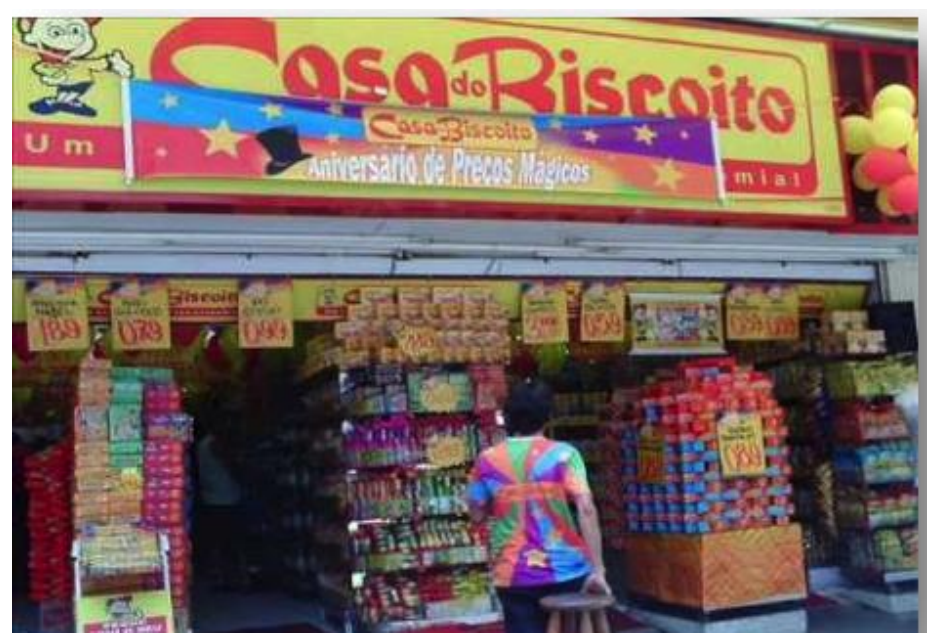

Fonte: Arquivos internos Casa do Biscoito (2004)

Figura 6 - Casa do Biscoito - Mudança de layout

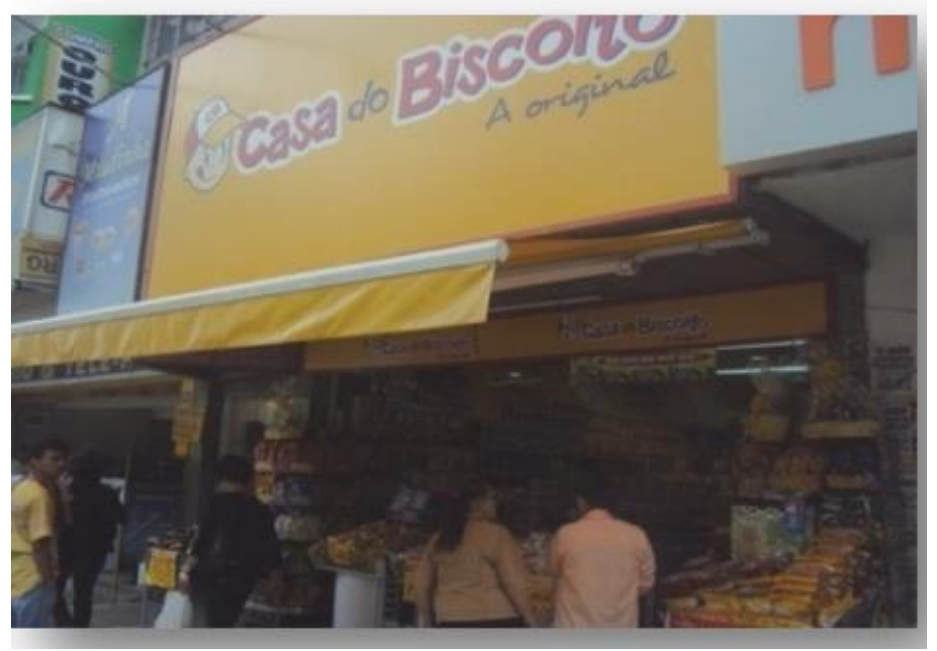

Fonte: Arquivos internos Casa do Biscoito (2013) 
Figura 7 - Casa do Biscoito - Modernização da fachada

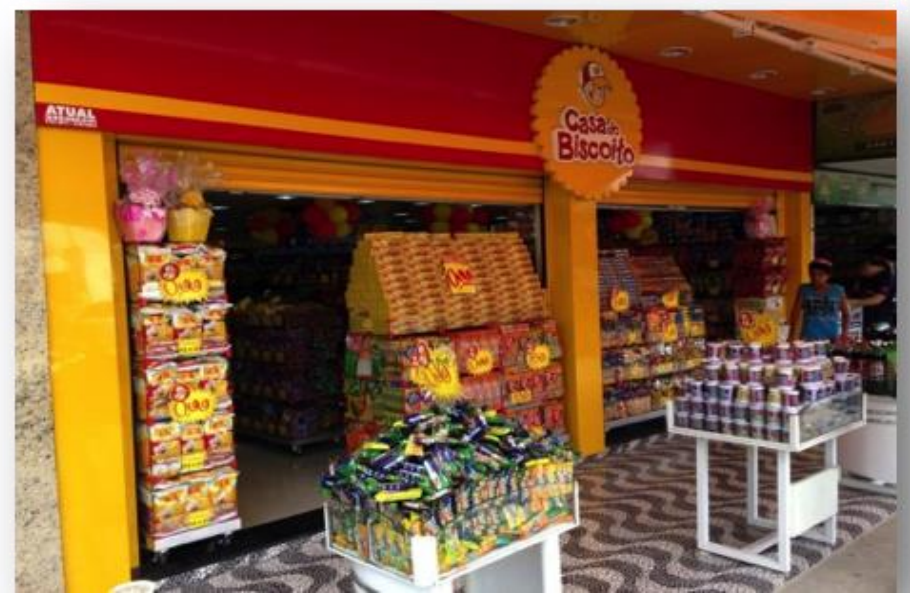

Fonte: Arquivos internos Casa do Biscoito (2014) 


\section{Apresentação e análise dos resultados}

Este capítulo tem o propósito de expor os resultados da pesquisa produzida e a análise realizada neles.

O capítulo está separado em 4 seções, primeiramente a amostra dos entrevistados, em segundo a análise da intenção de compra do consumidor perante a marca própria da empresa em questão, em terceiro será analisado questões sobre marca própria e por último, tópicos a respeito da empresa Casa do Biscoito.

\subsection{Descrição da amostra}

A pesquisa obteve uma amostra de 170 respondentes, a seguir será apresentado o perfil dos mesmos.

O gráfico 1 se diz respeito a idade dos respondentes:

\section{Gráfico 1 - Idade dos respondentes}

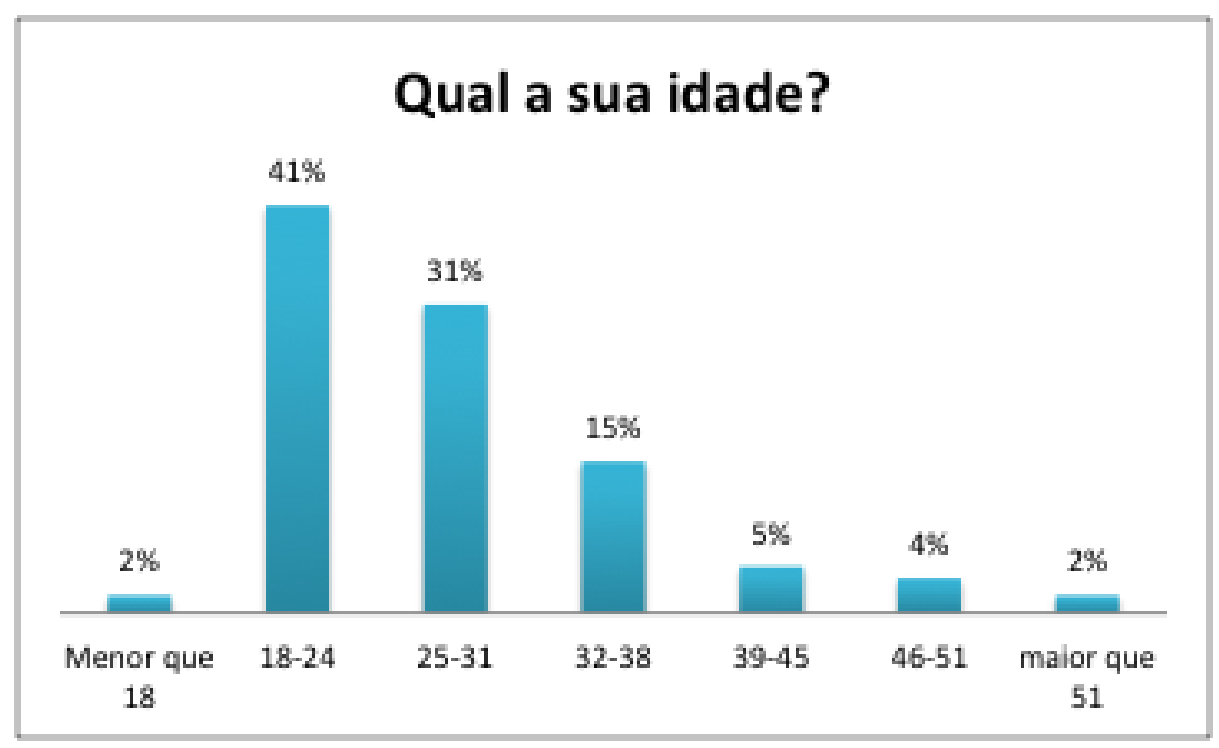

Fonte: Próprio autor (2019) 
As faixas do questionário foram divididas em: menores de 18 anos, 5 intervalos de 6 anos, sendo18-24, 25-31, 32-38, 39-45, 46-51 anos, e maiores de 51 anos.

Como se pode perceber, a grande maioria se encontra na faixa de 18-24 anos, com $41 \%$, representando quase metade da amostra.

Com a segunda maior porcentagem, a faixa de $25-31$ anos, com $31 \%$.

Em seguida, com 15\%, 32-38 anos.

E em pequenas porcentagens, menores de $18 \mathrm{com} 2 \%$, 39-45 anos com $5 \%, 46-51$ anos $4 \%$ e maiores de 51 anos com $2 \%$.

Sendo assim, 98\% dos respondentes são maiores de idade e possivelmente economicamente ativos.

Em seguida, foi questionado sobre o sexo do respondente (gráfico 2):

\section{Gráfico 2 - Sexo dos respondentes}

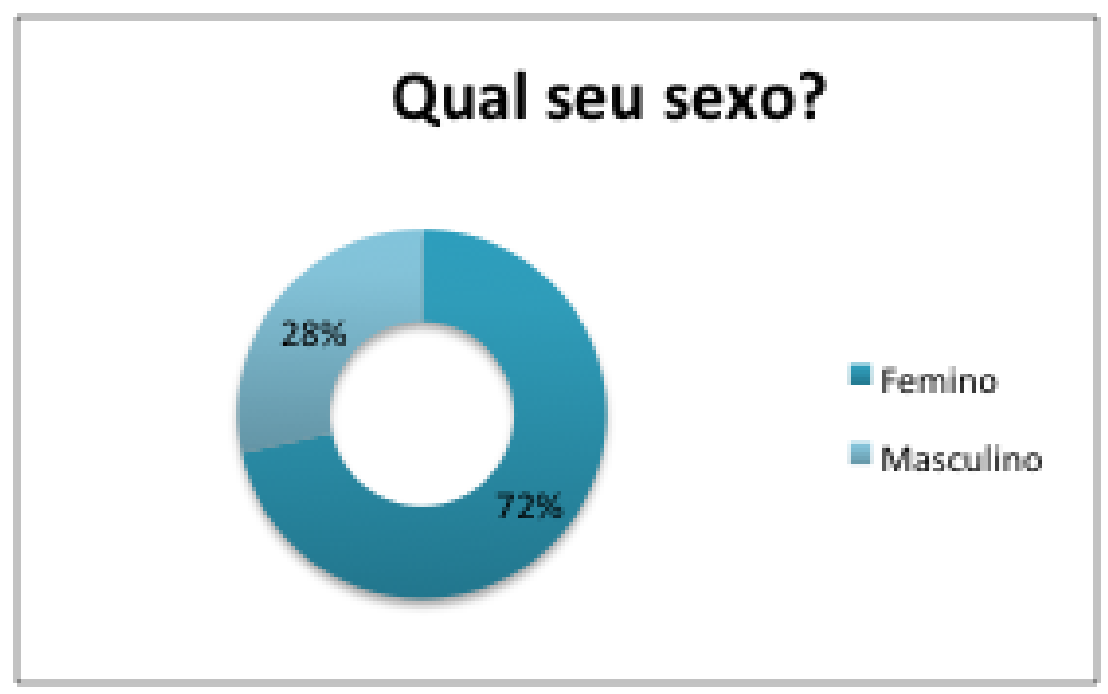

Fonte: Próprio autor (2019)

A grande maioria é do sexo feminino, correspondendo a $72 \%$ da amostra, apenas $28 \%$ é de sexo masculino.

Alguns dos fatores para essa desproporção são: quando houve a pesquisa presencial, era muito maior o número de consumidores do sexo feminino e quando foi passada a pesquisa online, devido a cultura brasileira de mulheres fazendo compras, é possível que muitos não se sentiram motivados a responder. 
Ao perguntar sobre a escolaridade, foi obtida a divisão exposta no gráfico 3:

\section{Gráfico 3 - Escolaridade dos respondentes}

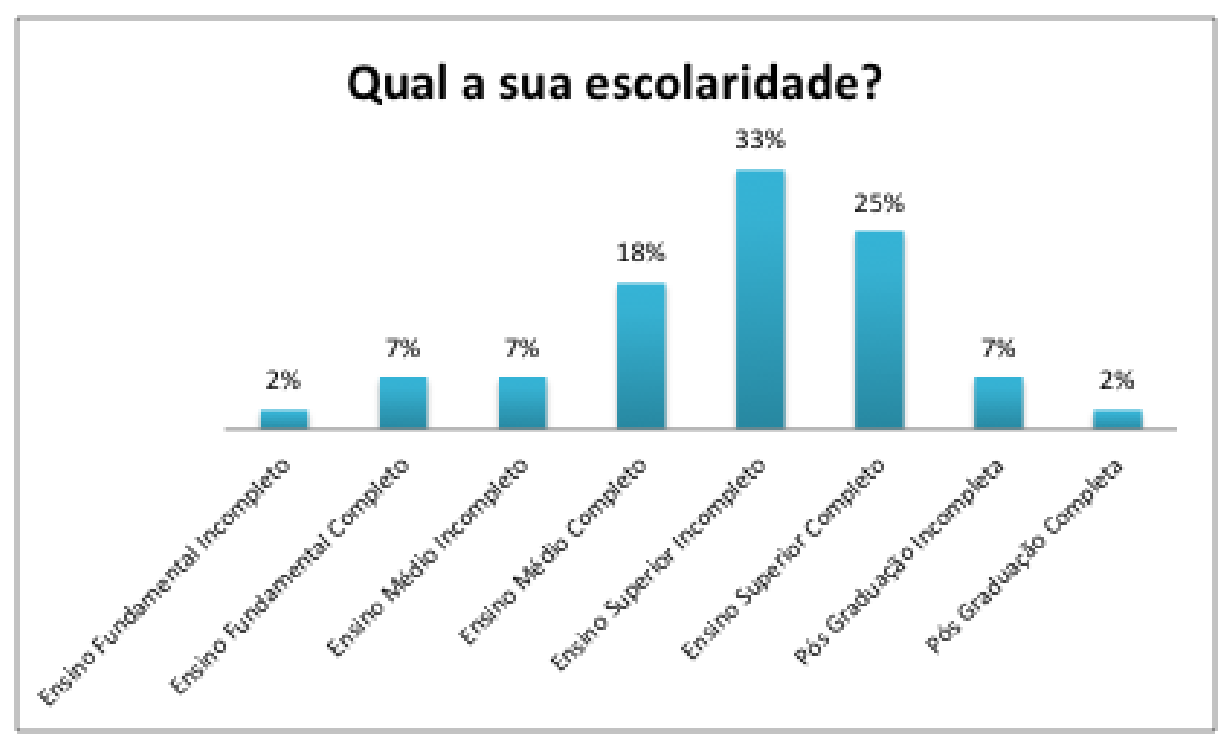

Fonte: Próprio autor (2019)

Em primeiro lugar, 33\% têm ensino superior incompleto, em segundo lugar com $25 \%$, ensino superior completo, representando a maioria dos respondentes.

Em terceiro lugar, $18 \%$ dos entrevistados obtêm ensino médio completo.

Abaixo de ensino médio completo, temos $2 \%$ com ensino fundamental incompleto, $7 \%$ com ensino fundamental completo e $7 \%$ com ensino médio incompleto.

Acima de ensino superior completo, 7\% tem pós-graduação incompleta e $2 \%$ pós-graduação completa.

Com isso, é possível concluir, que a maioria dos entrevistados, possuem um nível de escolaridade razoável, tendo em vista que $85 \%$ tiveram seu ensino médio completo, para mais.

A pergunta a seguir, teve o propósito de obter a renda dos respondentes (gráfico 4): 


\section{Gráfico 4 - Renda dos respondentes}

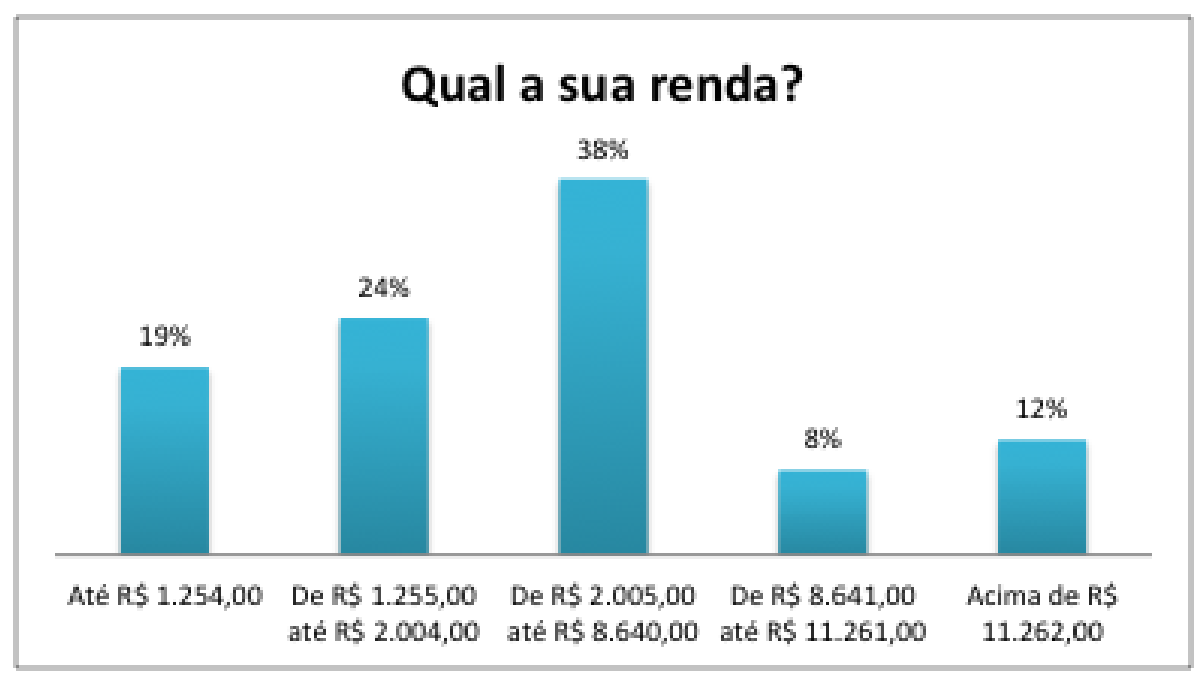

Fonte: Próprio autor (2019)

As opções de renda, foram distribuídas no questionário de acordo com o Centro de Políticas Sociais da FGV (2014).

Sendo dividida em: até $R \$ 1.254,00$ classe $E$, de $R \$ 1.255,00$ até $R \$$ $2.004,00$ classe $D$, de $R \$ 2.005,00$ até $R \$ 8.640,00$ classe $C$, de $R \$ 8.641,00$ até $R \$ 11.261,00$ classe $B$ e por fim, acima de $R \$ 11.262,00$ classe $A$.

Com isso, analisando o gráfico 4, concluímos que a maioria dos respondentes se encaixam na classe $C$, com $38 \%$, em seguida $24 \%$ são de classe $D, 19 \%$ de classe $E, 12 \%$ são de classe $A$ e $8 \%$ de classe $B$.

Posteriormente, foi perguntado com quem mora atualmente (gráfico 5): 
Gráfico 5 - Com quem o respondente mora atualmente

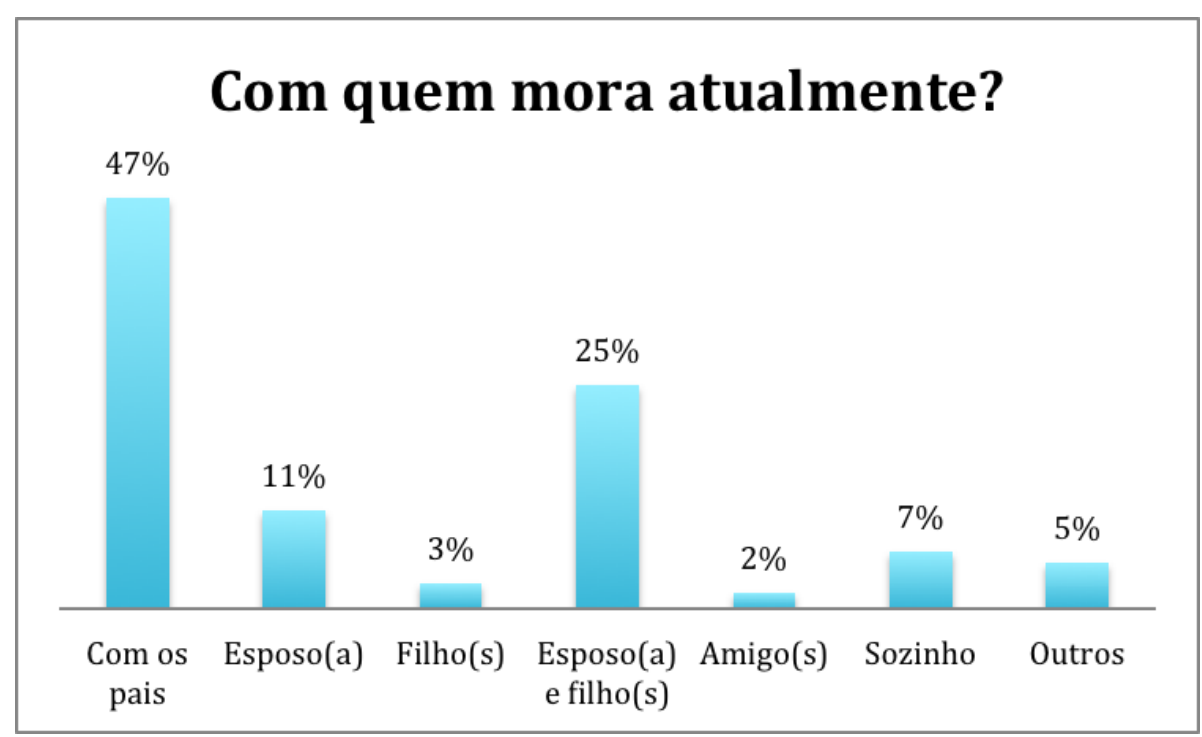

Fonte: Próprio autor (2019)

Esta pergunta teve o objetivo de analisar, se existe relação entre a quantidade de vezes que compra na empresa estudada com quem mora atualmente.

Este resultado será detalhado posteriormente.

Sendo assim, é notório que a grande maioria, $47 \%$ mora com os pais, em seguida $25 \%$ moram com esposo(a) e filho(s), $11 \%$ apenas com esposo(s), $7 \%$ mora sozinho, $2 \%$ com amigo(s) e $5 \%$ outros.

Ao perguntar sobre onde os respondentes residem, foram obtidos os seguintes resultados (gráfico 6): 


\section{Gráfico 6 - Onde reside os respondentes}

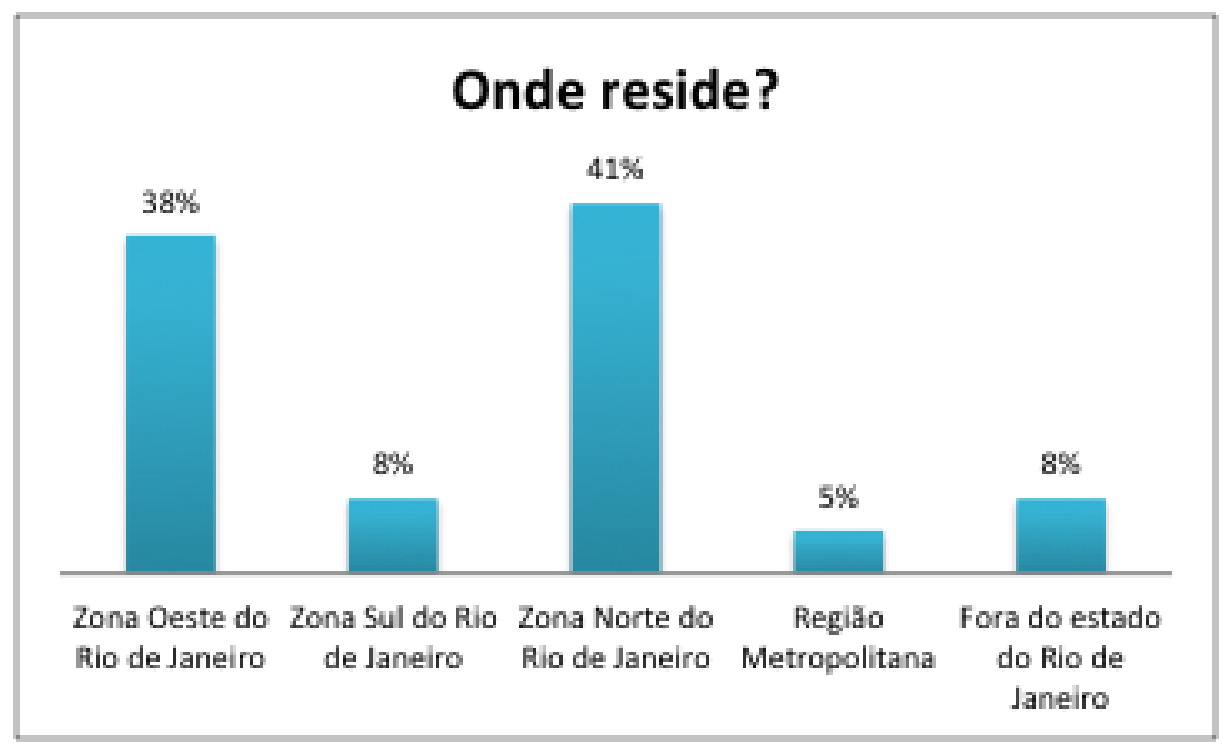

Fonte: Próprio autor (2019)

Tendo em vista que a empresa estudada possui lojas tanto no Rio de Janeiro, capital e região metropolitana, e alguns estados fora do Rio, como já mencionado, esta pergunta teve o objetivo de averiguar de onde são os respondentes.

Sendo assim, $41 \%$ são da Zona Norte do Rio de Janeiro, 38\% da Zona Oeste do Rio de Janeiro, 8\% da Zona Sul do Rio de Janeiro, 8\% são de fora do estado do Rio de Janeiro e 5\% da Região Metropolitana.

Por fim, a última pergunta era a respeito da profissão do respondente (gráfico 7): 


\section{Gráfico 7 - Profissão dos respondentes}

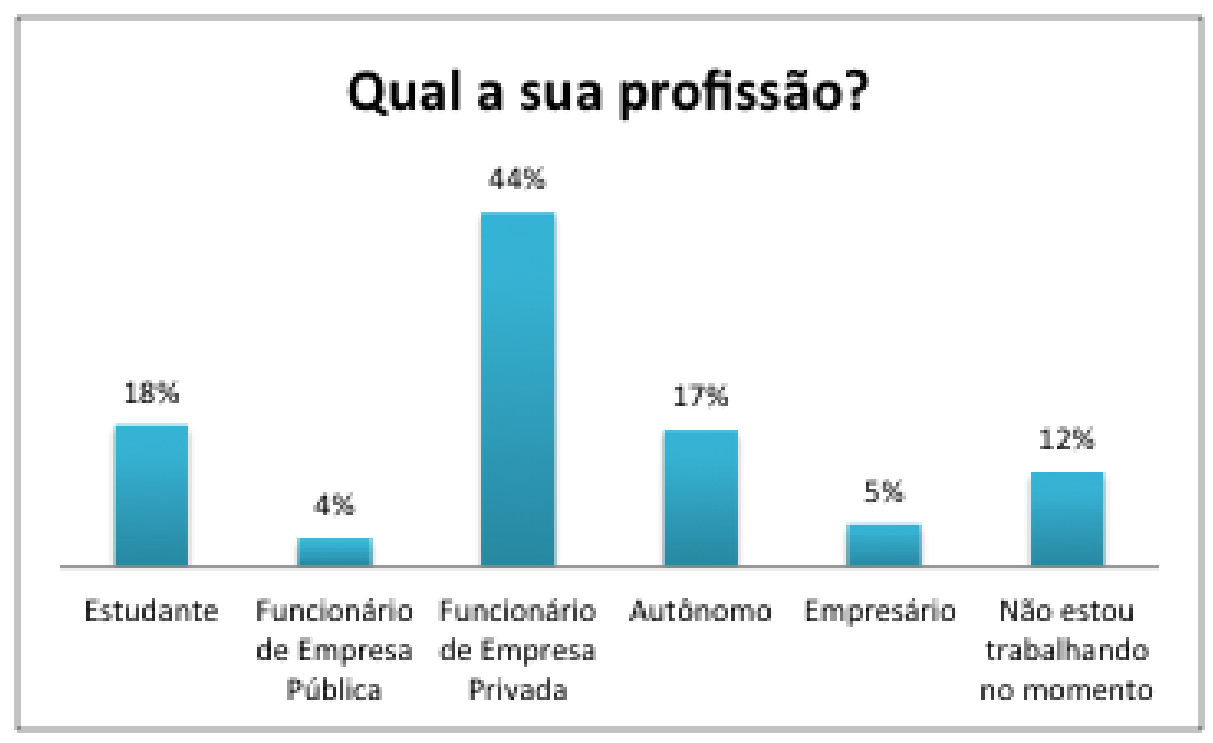

Fonte: Próprio autor (2019)

Quase metade dos respondentes, 44\% são funcionários de empresa privada, em seguida $18 \%$ são estudantes, $17 \%$ autônomos, $12 \%$ não estão trabalhando no momento, $5 \%$ são empresários e $4 \%$ funcionários de empresa pública.

\subsection{Análise da intenção de compra do consumidor perante marca própria}

Nesta parte da pesquisa, o objetivo foi o de avaliar a intenção de compras do consumidor diante da marca própria da Casa do Biscoito.

Sendo assim, foram comparados dois produtos de marca de fabricante com dois de marca própria, a diferença entre marca fabricante e marca própria foi detalhada no capítulo 2 , na seção 2.2.1.

Os produtos escolhidos foram: Panettone/Chocottone e Biscoito Salgadinho.

A primeira questão foi aberta e perguntava ao respondente quanto ele pagaria, em reais, pelo panettone/chocottone da marca Bauducco: 


\section{Figura 8 - Panettone/Chocottone Bauducco}

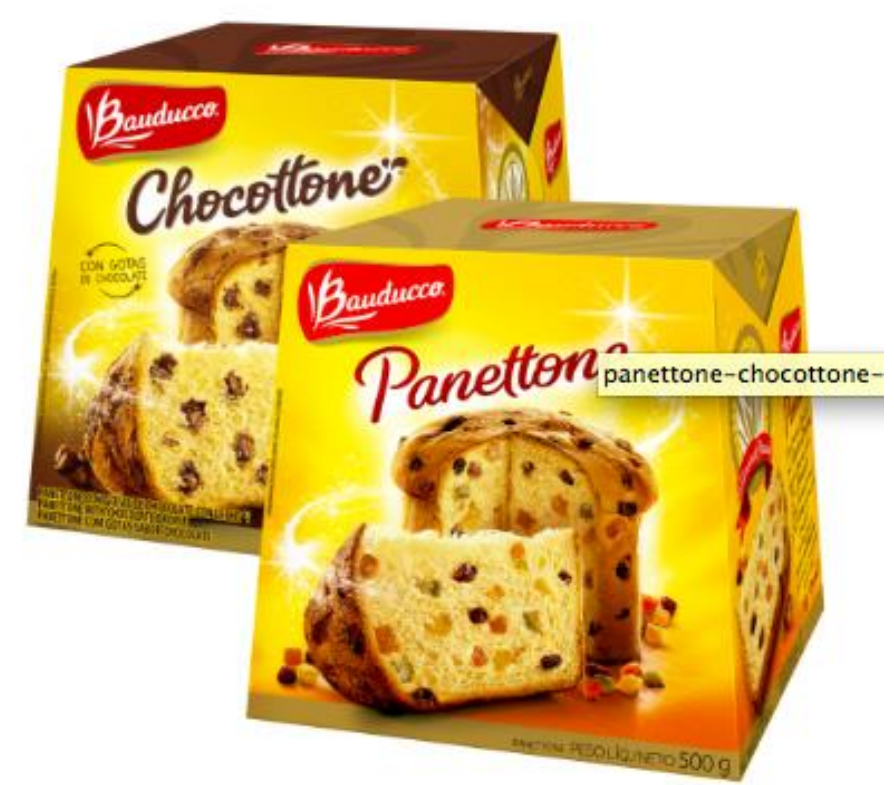

Fonte: Cercadão Supermercados (2018)

A média de preço foi de $R \$ 14,47$, para 170 respondentes

O preço deste produto é em média de: $R \$$ 15,90 (Preço médio de mercado)

Sendo assim, podemos concluir que o preço a ser pago pelos consumidores que participaram da pesquisa, está um pouco menor, porém é bem próximo do preço aplicado pelos varejistas.

Em seguida, utilizando a escala Juster, que avalia de 0 a 10 a probabilidade de compra, foi perguntando na segunda questão o quão provável o respondente compraria o produto acima, para então avaliar a sua intenção de compra.

A média obtida foi de 6,2, ou seja, a intenção de compra do panettone/chocottone Bauducco é de $62 \%$.

A próxima etapa, foi igual a de cima, porém em relação ao Panettone/Choccotone da marca Casa do Biscoito, então na terceira questão foi perguntado de forma aberta, o quanto o respondente pagaria, em reais, pelo panettone/chocottone da marca própria da loja: 
Figura 9 - Panettone/Chocottone Casa do Biscoito

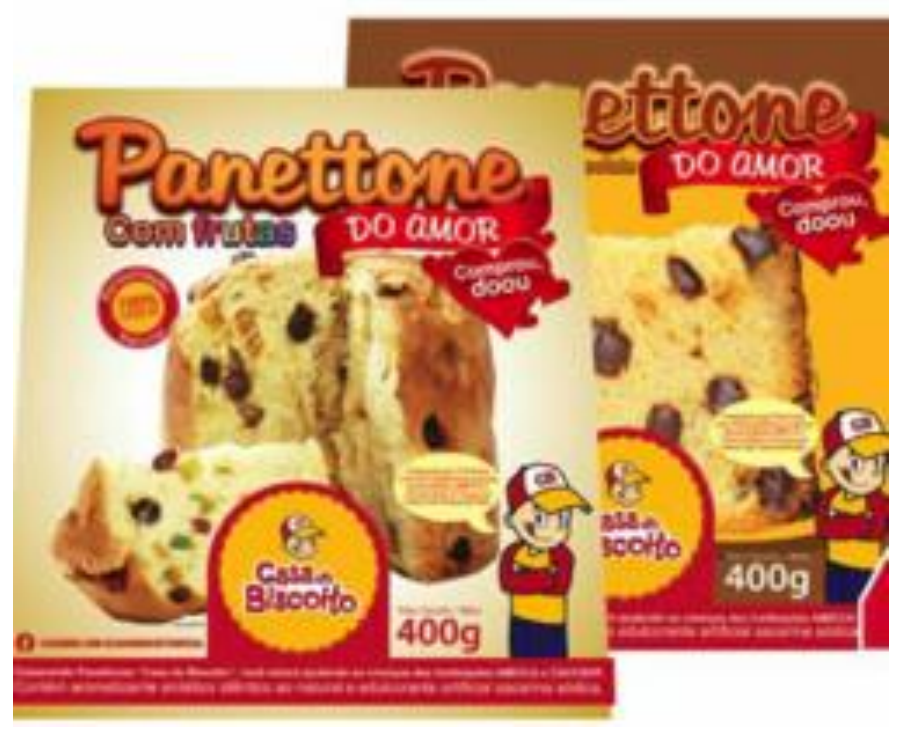

Fonte: Casa do Biscoito (2018)

A média de preço foi de $R \$ 10,55$, para 170 respondentes.

O preço nas lojas da Casa do Biscoito desse produto é de $R \$ 6,99$, sendo assim, podemos perceber que os consumidores avaliam este produto com um preço acima do que ele realmente é.

A quarta pergunta tinha o objetivo de avaliar a escala Juster, conforme descrito acima.

A média foi de 6 , ou seja, $60 \%$ de intenção de compra.

Em relação ao segundo produto, o biscoito salgadinho, foi feita a mesma sequência de perguntas, comparando os dois.

Sendo assim, a quinta questão foi perguntando quanto pagaria, em reais, no salgadinho Torcida (80 gramas): 


\section{Figura 10 - Biscoito salgadinho Torcida}

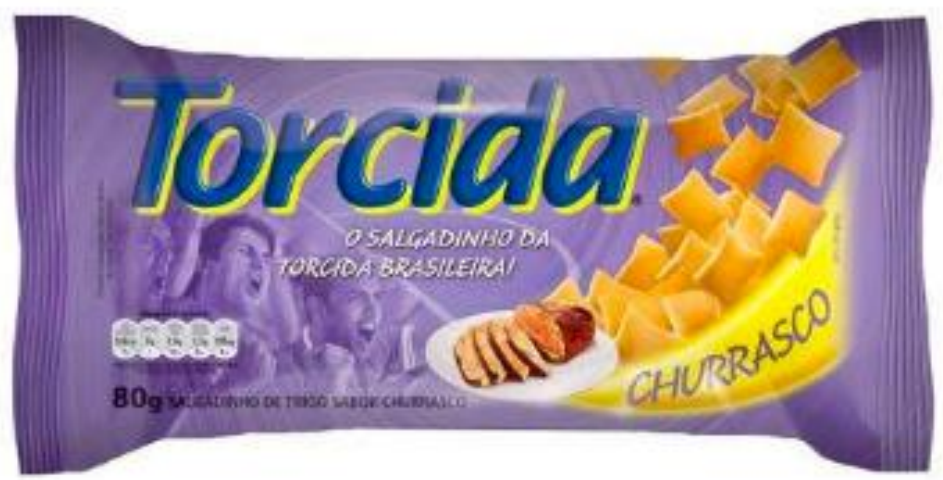

Fonte: Americanas.com (2019)

A média de preço foi de $\mathrm{R} \$ 1,90$, para 170 respondentes.

O preço médio desse produto é de $\mathrm{R} \$ 1,78$ (Preço médio de mercado)

Ou seja, a média dos respondentes deu maior, porém muito próxima.

Na sexta questão, em relação a escala Juster, foi obtido a média de 7,1 , ou seja $71 \%$ de intenção de compra.

Comparando ao salgadinho Casa do Biscoito (60 gramas), na sexta questão obtemos os seguintes resultados na pergunta aberta sobre quanto o respondente pagaria, em reais pelo produto:

\section{Figura 11 - Biscoito salgadinho Casa do Biscoito}

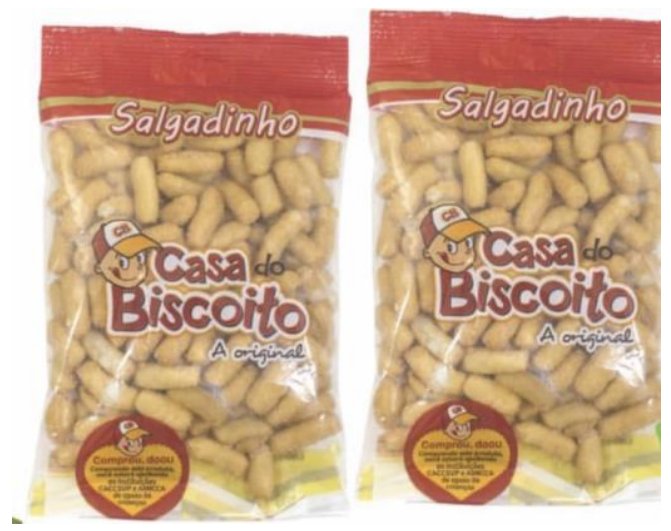

Fonte: Casa do Biscoito (2019)

A média de preço foi de $R \$ 1,87$, para 170 respondentes. 
O produto é vendido na Casa do Biscoito por $R \$ 0,99$, sendo assim, a conclusão que se tira, é que os respondentes consideram pagar um valor mais alto do que está no momento.

Na sétima questão, analisando através da escala Juster, se teve uma média de 7 , sendo assim, $70 \%$ de intenção de compra.

Analisando esta etapa de uma maneira geral, podemos perceber que o valor médio dado pelos respondentes aos produtos de marca própria, são menores que os de marca fabricante, o que já era de se esperar, visto que, conforme citado no referencial teórico, a proposta da marca própria é trazer menores valores ao público frente aos de marca fabricante.

Ao compararmos os valores médios respondidos com os valores aplicados pelos varejistas, podemos perceber que o valor que o consumidor pagaria pelos produtos de marca fabricante, é bem próximo do valor já aplicado, já o valor dado aos produtos de marca própria, são um pouco maiores que o valor já aplicado.

Sendo assim, podendo ter uma oportunidade de explorar mais a margem de lucro.

Ao avaliarmos a intenção de compra, ao compararmos os produtos de marca fabricante com os de marca própria, Bauducco com Casa do Biscoito e Torcida com Casa do Biscoito, ambas são acima da média e bem próximas uma da outra.

Com isso, pode-se confirmar o que já foi mencionado no capítulo 2, que a geração atual de marca própria está no mercado para gerar valor para o varejista e para o atacadista e competir diretamente com as marcas de fabricante.

Quando comparamos os diferentes produtos, ou seja, Panettone/Chocottone, com o biscoito salgadinho, pode-se perceber que a intenção de compra do biscoito salgadinho é $10 \%$ maior, talvez por se tratar de um produto do cotidiano, por não participar de uma data comemorativa, como o Natal e por ser mais barato.

\subsection{Análise Marca Própria}

Esta etapa da pesquisa teve o intuito de analisar a relação que os consumidores têm com qualquer produto de marca própria. 
A primeira questão desta parte, perguntava com que frequência 0 respondente costuma comprar produtos de marca própria:

Gráfico 8 - Frequência que os respondentes compram produtos de marca própria

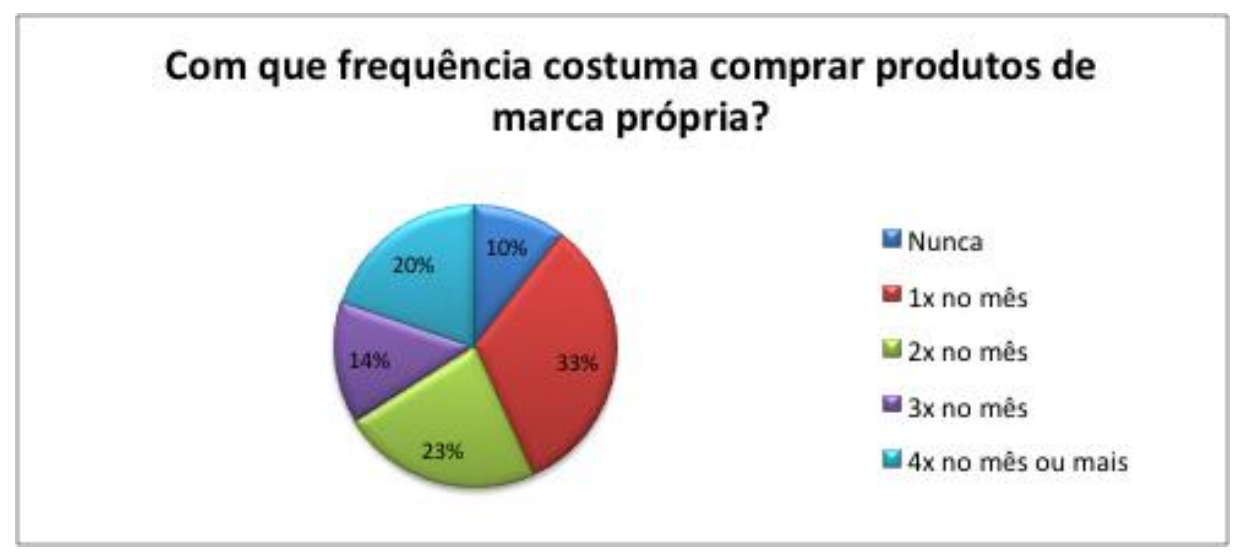

Fonte: Próprio autor (2019)

Os resultados colhidos foram, 33\% compram pelo menos 1 vez no mês, $23 \%$ compram pelo menos 2 vezes no mês, $20 \%$ compram 4 vezes no mês ou mais, 14\% compram 3 vezes no mês e 10\% nunca compram produtos de marca própria.

Ou seja, 90\% dos respondentes têm experiência, nem que uma vez por mês, com produtos de marca própria, um número bem alto a ser explorado.

A segunda questão, pedia para avaliar numa escala de 1 a 5 , onde 1 é pouco e 5 é muito, o quanto avaliam a qualidade desses produtos.

Esta pergunta teve a finalidade de avaliar se os consumidores ainda estão relacionando produtos de marca própria à baixa qualidade, devido às suas primeiras gerações, conforme mencionado no capítulo 2 .

\section{Tabela 2 - Média de Qualidade}

\section{Média de qualidade total dos entrevistados}

Fonte: Próprio autor (2019)

A média obtida dentre todos os respondentes foi de 3,8 , ou seja, classificam como mediana pra alta a qualidade dos produtos.

E então, pode-se perceber que a percepção dos consumidores mudou. 
Ao cruzarmos as respostas da pergunta sobre a qualidade e quantas vezes adquire produtos de marca própria no mês, se obteve a seguinte relação:

Gráfico 9 - Média de qualidade $\mathrm{x}$ quantidade de vezes por semana que 0 respondente compra marca própria

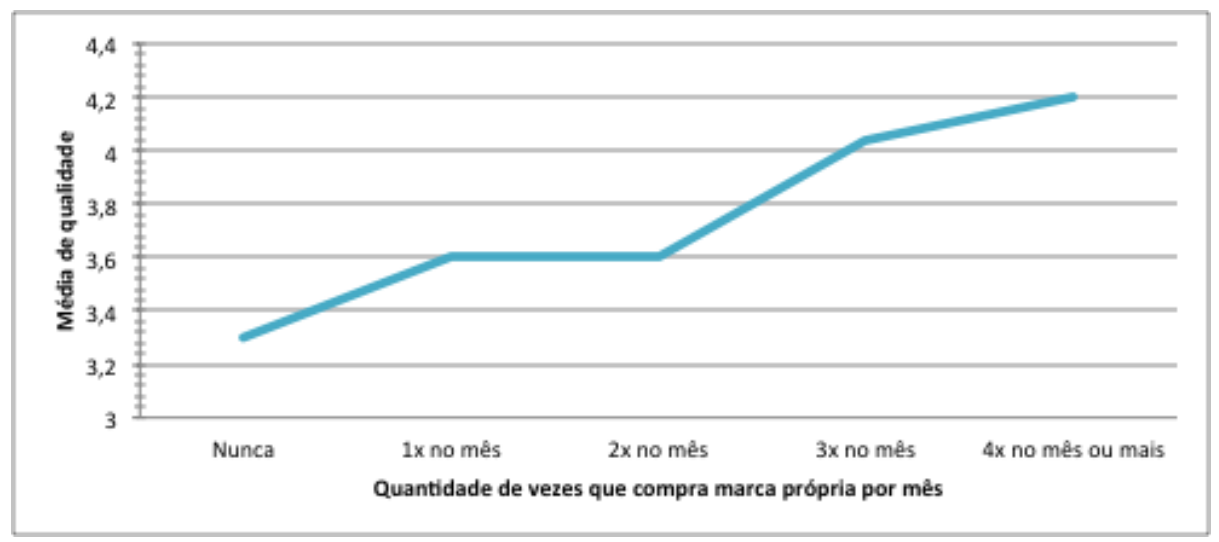

Fonte: Próprio autor (2019)

A média sobre a qualidade é paralelamente crescente, de acordo com os que a compram mais vezes por mês.

Isto é, quanto mais os consumidores compram produtos de marca própria, melhor eles avaliam a qualidade dos mesmos.

Em seguida, foi perguntado sobre os fatores que o influenciam a adquirir um produto de marca própria:

Gráfico 10 - Fatores que influenciam o respondente a adquirir marca própria

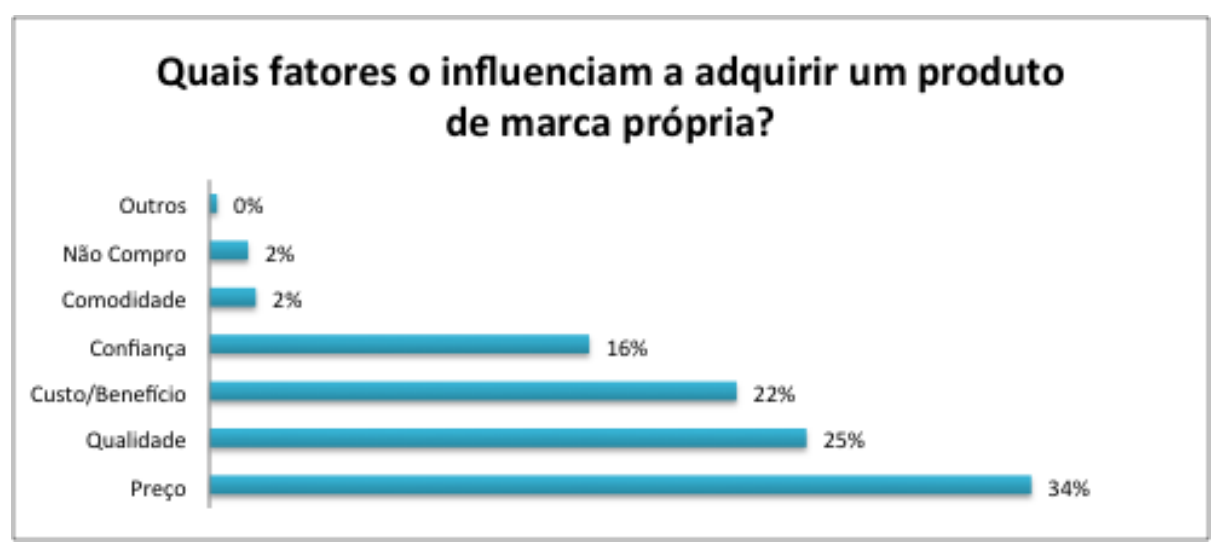

Fonte: Próprio autor (2019) 
Os resultados colhidos foram, 34\% revelam que o motivo é o do preço ser mais em conta, $25 \%$ pela qualidade do produto, $22 \%$ pelo custo-benefício, $16 \%$ pela confiança no produto/marca, $2 \%$ não compram e $0 \%$ escolheram a opção outros.

Sendo assim, confirmando o que foi mencionado no capítulo 2, a respeito do preço dos produtos de marca própria ser um diferencial competitivo para o varejista.

Pode-se perceber também a inconsistência que existe no gráfico $10 \mathrm{em}$ relação ao gráfico 8 , visto que, no gráfico $810 \%$ dos respondentes nunca comprou marca própria, porém, nesta questão apontou os fatores que o fazem comprar marca própria.

A próxima questão, interrogava como o respondente chega até um produto de marca própria pela primeira vez:

Gráfico 11 - Como o respondente costuma chegar pela primeira vez a um produto de marca própria

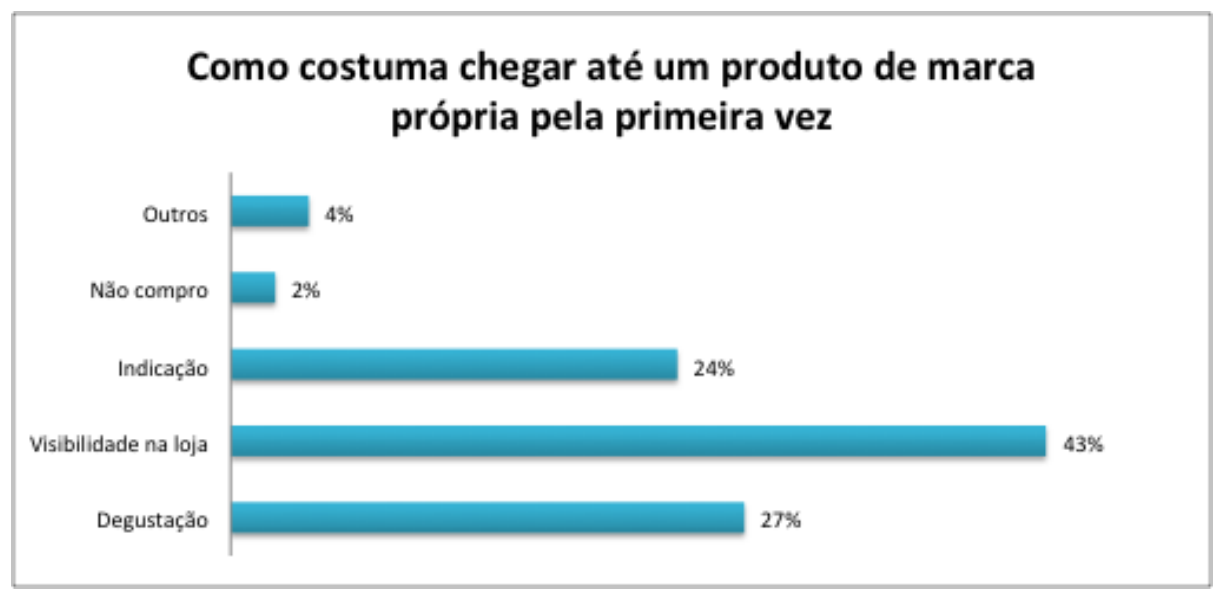

Fonte: Próprio autor (2019)

A grande maioria, $43 \%$ dos respondentes, é persuadido pela exposição do produto, ou seja, por estar em um local no estabelecimento fácil de ser visto, em segundo lugar, com $27 \%$ a degustação, visto que, quando o consumidor tem a oportunidade de degustar, o risco de não gostar do produto, de ser um dinheiro mal gasto, entre outros fatores, cai totalmente, sendo assim, a degustação abre muitas portas para novos produtos; em terceiro indicação, o boca a boca informal influencia bastante, na opção outros, com 4\%, por ser um campo aberto no questionário, mencionaram a curiosidade como um fator e por fim $2 \%$ não compram. 
A mesma inconsistência em relação ao gráfico 8 que ocorreu no gráfico 10, também aparece no gráfico 11 , dado que, no gráfico $8,10 \%$ dos respondentes disseram que nunca compram produtos de marca própria, porém opinou sobre o motivo que o faz chegar até um produto de marca própria pela primeira vez.

Os varejistas devem expor seus produtos de marca própria de forma que os consumidores possam vê-los constantemente e sempre que possível fazer ações de degustação para atrair novos compradores e inserir seu produto nas opções de compra dos clientes.

Tabela 3 - Renda x Quantas vezes o respondente compra marca própria

\begin{tabular}{|c|c|c|c|c|c|c|}
\hline $\begin{array}{l}\text { Renda x } \\
\text { Quantas } \\
\text { vezes compra } \\
\text { marca } \\
\text { própria por } \\
\text { mês }\end{array}$ & $1 \times$ por mês2 & s $2 x$ por mês & $3 x$ por mês & $\begin{array}{c}\text { 4x por } \\
\text { mês ou } \\
\text { mais }\end{array}$ & Nunca & Total \\
\hline Classe A & $37 \%$ & $16 \%$ & $21 \%$ & $10 \%$ & $16 \%$ & $100 \%$ \\
\hline Classe B & $7 \%$ & $43 \%$ & $14 \%$ & $7 \%$ & $29 \%$ & $100 \%$ \\
\hline Classe C & $35 \%$ & $28 \%$ & $8 \%$ & $18 \%$ & $11 \%$ & $100 \%$ \\
\hline Classe D & $36 \%$ & $21 \%$ & $15 \%$ & $28 \%$ & $0 \%$ & $100 \%$ \\
\hline Classe E & $29 \%$ & $16 \%$ & $19 \%$ & $26 \%$ & $10 \%$ & $100 \%$ \\
\hline
\end{tabular}

Fonte: Próprio autor (2019)

A tabela 3, cruza duas informações, renda dos respondentes $x$ quantas vezes por mês compra produtos de marca própria.

Com isso, é de se analisar que a maioria da classe A, C, D e E compram 1x por mês, 37\%, 35\%, 36\% e 29\% respectivamente.

A classe $B$, tem sua maioria comprando $2 x$ ao mês, com $43 \%$.

Em compensação, as classes menores como C,D e E tem os menores percentuais na opção "Nunca", por exemplo, a classe $D$ não teve nenhum respondente que nunca compra, todos pelo menos compram $1 \mathrm{x}$ no mês.

\subsection{Análise Empresa Casa do Biscoito}

A última etapa da pesquisa, conforme já mencionado anteriormente, teve a finalidade de avaliar quesitos relacionados a empresa estudada. 
A primeira questão desta etapa, perguntava sobre os produtos de marca própria da Casa do Biscoito e a relação que o respondente tem com o mesmo:

Gráfico 12 - Respondentes sobre os produtos de marca própria da Casa do Biscoito

\section{Sobre produtos de marca própria Casa} do Biscoito

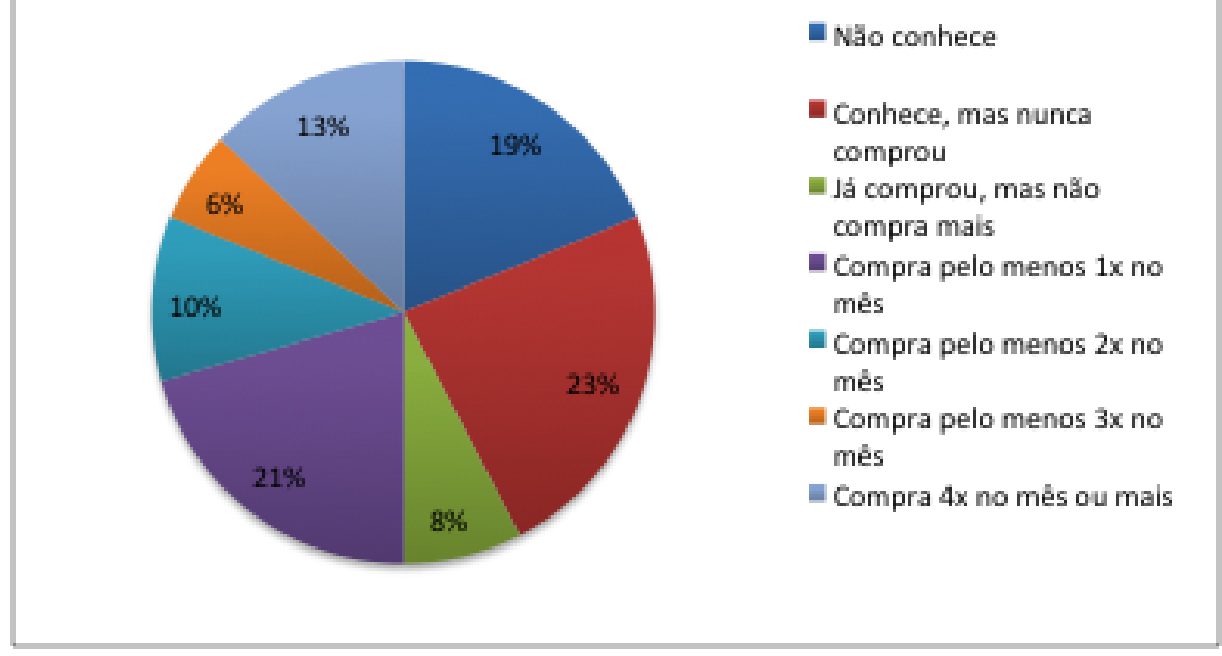

Fonte: Próprio autor (2019)

Com base no gráfico 12 , podemos perceber que, $50 \%$ não compram os produtos de marca própria da loja, pois 19\% não conhecem, 23\% conhecem porém nunca compraram e $8 \%$ já comprou, porém não compram mais. Um número alto, pois $90 \%$ dos respondentes (Gráfico 10) adquire produtos de marca própria, ou seja, é necessário um plano estratégico para inserir os produtos de marca própria da Casa do Biscoito na compra dos consumidores.

Os outros $50 \%$ adquirem os produtos de marca própria da Casa do Biscoito, sendo divididos em $21 \%$ compra pelo menos $1 x$ no mês, $10 \%$ compra pelo menos $2 x$ no mês, $6 \%$ compra $3 x$ no mês e $13 \%$ compra $4 x$ no mês ou mais.

Posteriormente, foi questionado ao respondente a frequência com que ele costuma comprar quaisquer produtos na Casa do Biscoito: 
Gráfico 13 - Frequência que o responde costuma comprar quaisquer produtos na Casa do Biscoito

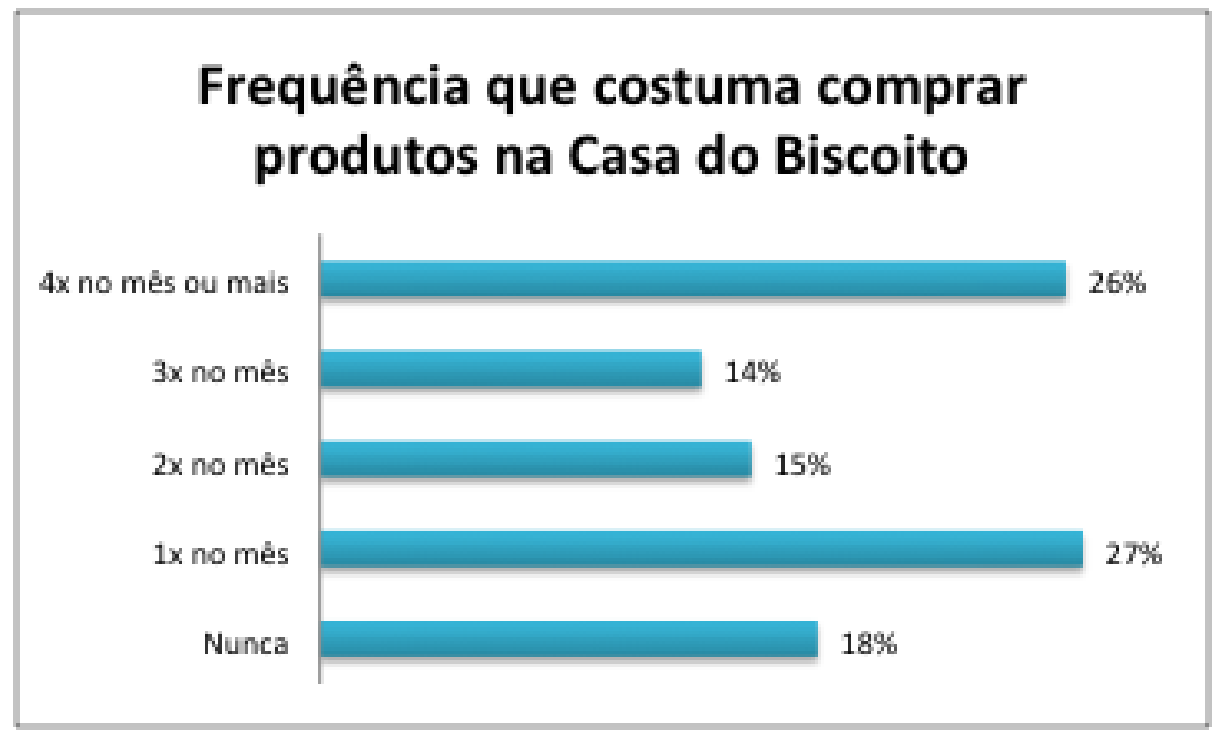

Fonte: Próprio autor (2019)

E então, 18\% nunca compram na Casa do Biscoito, porém temos uma amostra de $82 \%$ que compram todo mês, mesmo que apenas $1 \mathrm{x}$.

Os números são divididos em $27 \%$ compra 1 x no mês, $26 \%$ compra $4 x$ no mês ou mais, ou seja, o equivalente a pelo menos $1 x$ na semana, 15\% compra $2 x$ no mês e $14 \%$ compra $3 x$ no mês.

A questão a seguir, visou avaliar, numa escala de 1 a 5 , onde 1 é nada satisfeito e 5 é muito satisfeito, alguns compostos do varejo, mencionados no capítulo 2, seção 2.1, como: preço, atendimento, variedade, facilidade de encontras os produtos (exposição), localização e por fim avaliar também a qualidade e os produtos de marca própria. 


\section{Gráfico 14 - Grau de satisfação sobre itens avaliados da Casa do Biscoito}

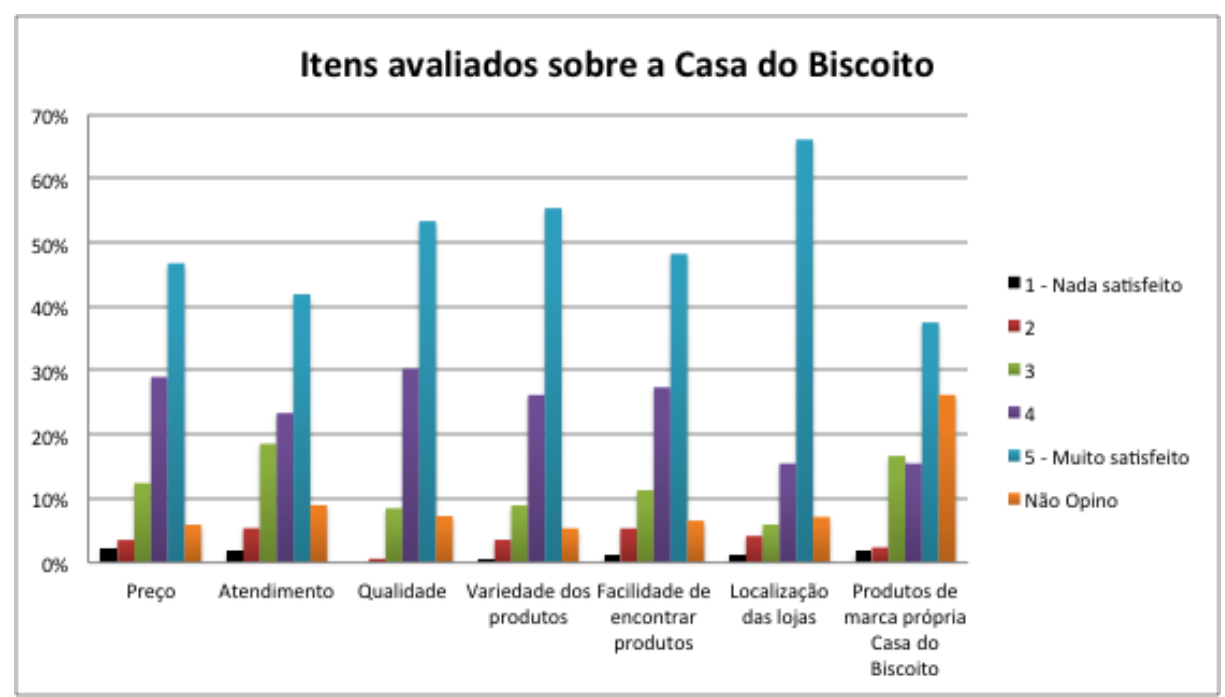

Fonte: Próprio autor (2019)

No gráfico 14, é possível perceber que a maioria das respostas estão avaliando em 4 e 5, o que é realmente muito bom, pois está bem acima da média na visão dos consumidores.

$\mathrm{Na}$ Tabela 4, pode-se analisar a média de cada item:

Tabela 4 - Média dos itens avaliados

\begin{tabular}{|l|c|}
\hline & Média \\
\hline Preço & 4,2 \\
\hline Atendimento & 4,1 \\
\hline Qualidade & 4,5 \\
\hline Variedade dos produtos & 4,4 \\
\hline Facilidade de encontrar produ & 4,2 \\
\hline Localização das lojas & 4,5 \\
\hline $\begin{array}{l}\text { Produtos de marca própria } \\
\text { Casa do Biscoito }\end{array}$ & 4,2 \\
\hline
\end{tabular}

Fonte: Próprio autor (2019)

As médias mais altas são os itens qualidade e localização das lojas, com 4,5; já a média mais baixa é o atendimento com 4,1, mas ainda sim é uma boa pontuação, podendo-se dizer que é resultado de uma boa gestão.

Também foi relacionado: Com quem mora atualmente x Quantas vezes compra na Casa do Biscoito: 
Tabela 5 - Com quem mora x Quantas vezes compra na Casa do Biscoito

\begin{tabular}{|c|c|c|c|c|c|c|}
\hline $\begin{array}{l}\text { Com quem mora/ Quantas } \\
\text { vezes compra na Casa do } \\
\text { Biscoito }\end{array}$ & $1 x$ & $2 x$ & $3 x$ & $4 \mathrm{x}$ ou mais & Nunca & Total \\
\hline Pais & $24 \%$ & $18 \%$ & $11 \%$ & $16 \%$ & $30 \%$ & $100 \%$ \\
\hline Esposo(a) & $37 \%$ & $0 \%$ & $5 \%$ & $53 \%$ & $5 \%$ & $100 \%$ \\
\hline Filho(s) & $20 \%$ & $20 \%$ & $20 \%$ & $40 \%$ & $0 \%$ & $100 \%$ \\
\hline Esposo(a) e filho(s) & $21 \%$ & $19 \%$ & $21 \%$ & $37 \%$ & $2 \%$ & $100 \%$ \\
\hline Amigos & $67 \%$ & $0 \%$ & $0 \%$ & $33 \%$ & $0 \%$ & $100 \%$ \\
\hline Sozinho & $33 \%$ & $22 \%$ & $22 \%$ & $11 \%$ & $11 \%$ & $100 \%$ \\
\hline Outros & $33 \%$ & $22 \%$ & $22 \%$ & $11 \%$ & $11 \%$ & $100 \%$ \\
\hline
\end{tabular}

Fonte: Próprio autor (2019)

E então, com base na Tabela 5 , pode-se perceber que a maioria dos respondentes que moram com os pais, 30\%, nunca compram na Casa do Biscoito, já os que moram com seu/sua esposo(a), filho(s) ou esposo(a) e filho(s) a maioria compra $4 x$ no mês ou mais, com $53 \%, 40 \%$ e $37 \%$ respectivamente, por fim quem mora com amigos, sozinho ou outros, a maioria compra $1 \mathrm{x}$ por mês, com $67 \%$, 33\% e $33 \%$ respectivamente.

A finalidade deste cruzamento, foi a de definir quem são seus consumidores mais frequentes, e então, a Casa do Biscoito poderá direcionar seu marketing com base nisso.

O último cruzamento de dados feito foi: Frequência que costuma comprar quais produtos na Casa do Biscoito x Relação com produtos de Marca Própria da Casa do Biscoito.

Tabela 6 - Compram quaisquer produtos na Casa do Biscoito x Compram produtos de marca própria da Casa do Biscoito

\begin{tabular}{|c|c|c|c|c|c|c|c|c|}
\hline $\begin{array}{l}\text { Compram na Casa do } \\
\text { Biscoito } x \text { Relação } \\
\text { com produtos de MP } \\
\text { da Casa do Biscoito }\end{array}$ & $\begin{array}{c}\text { Não } \\
\text { conhece }\end{array}$ & $\begin{array}{c}\text { Conhece } \\
\text { mas } \\
\text { nunca } \\
\text { compro } \\
\text { u }\end{array}$ & $\begin{array}{c}\text { Já } \\
\text { comprou } \\
\text { mas não } \\
\text { compra } \\
\text { mais }\end{array}$ & $\begin{array}{c}\text { 1x no } \\
\text { mês }\end{array}$ & $\begin{array}{c}2 \times \text { no } \\
\text { mês }\end{array}$ & $\begin{array}{c}3 x \text { no } \\
\text { mês }\end{array}$ & $\begin{array}{c}4 \times \text { no } \\
\text { mês ou } \\
\text { mais }\end{array}$ & Total \\
\hline 1x no mês & $26 \%$ & $24 \%$ & $11 \%$ & $39 \%$ & 0 & 0 & 0 & $100 \%$ \\
\hline 2x no mês & $4 \%$ & $44 \%$ & $4 \%$ & $8 \%$ & $40 \%$ & 0 & 0 & $100 \%$ \\
\hline $3 x$ no mês & $9 \%$ & $26 \%$ & $4 \%$ & $30 \%$ & $9 \%$ & $22 \%$ & 0 & $100 \%$ \\
\hline $4 x$ no mês ou mais & $7 \%$ & $9 \%$ & $0 \%$ & $13 \%$ & $13 \%$ & $11 \%$ & $47 \%$ & $100 \%$ \\
\hline
\end{tabular}

Fonte: Próprio autor (2019)

A conclusão que se tira da Tabela 10 é que $39 \%$ das pessoas que compram $1 x$ por mês na casa do biscoito, $40 \%$ dos que compram $2 x$ no mês, 
$22 \%$ que compram $3 x$ no mês e $47 \%$ que compram $4 x$ no mês, compram produtos de marca própria toda vez que vão lá.

Ou seja, são clientes fiéis não só a loja, como a marca própria da Casa do Biscoito também. 


\section{Conclusões e recomendações para novos estudos}

A partir das análises feitas no Capítulo 5, com base nos resultados adquiridos, ao analisarmos a pergunta problema deste estudo, que visava medir os impactos da marca própria na intenção de compra do consumidor, se pode concluir que a marca própria possui grande capacidade de ser considerada na hora da compra, visto que, foram obtidos resultados satisfatórios na escala Juster.

Foi possível analisar também que grande parte dos consumidores já inserem produtos de marca própria no seu dia a dia, e que esses produtos não são mais vistos como produtos de baixa qualidade, como eram nas suas primeiras gerações.

Pode-se dizer que o preço é o diferencial que mais se destaca e que a visibilidade na loja é o fator que mais atrai os consumidores.

No diagnóstico feito em relação aos produtos de marca Casa do Biscoito, pode-se concluir que boa parte dos consumidores não conhece/não compra os produtos de marca própria, com isso, sendo necessário uma maior atenção ao promovê-los.

Sendo assim, como sugestão, o que precisa ser feito pelos varejistas alimentícios e pela a Casa do Biscoito, é uma boa gestão da marca para potencializar a venda de seus produtos de marca própria, colocá-los em lugares visíveis ao consumidores, para chamar atenção, e sempre que possível fazer ações de degustações para apresentar os produtos aos clientes que não conhecem.

Em relação aos itens avaliados, como preço, localização, atendimento, etc, a Casa do Biscoito está muito bem avaliada, resultado de uma boa gestão.

\subsection{Sugestões e recomendações para novos estudos}

Este trabalho poderá servir como base para novos estudos, então é recomendado que nos próximos compare marcas próprias em outros setores, a fim de avaliar se os resultados serão os mesmos. 
Recomenda-se também fazer um estudo sobre a logística desses produtos para identificar quais as barreiras enfrentadas pelos varejistas. 


\section{Referências Bibliográficas}

AAKER, David A. Marcas Brand Equity: gerenciando o valor da marca. 5. ed. São Paulo: Negócio, 2003. xviii, 309 p.

ABMAPRO, Marca própria. Disponível em: <https://abmapro.org.br/sobre/marca-propria/> Acesso em 30 de set de 2018.

AMERICANAS, Salgadinho Torcida. Disponível em: $<$ https://www.americanas.com.br/produto/19542528/salgadinho-torcidachurrasco-80glucky?pfm_carac=salgadinho\%20torcida\&pfm_index=3\&pfm_page=search\&pfm pos=grid\&pfm_type=search_page\%20\&sellerld $>$ Acesso em: 10 de mai de 2019.

BARNEY, Jay B.; HESTERLY, William S. Administração estratégica e vantagem competitiva: casos e conceitos. 3. ed. São Paulo: Pearson Prentice Hall, c2011. xx, 408 p.

CERCADÃO, Panettone ou Chocottone Bauducco. Disponível em: http://www.cercadao.com.br/ofertas/mercearia/panettone-ou-chocottonebauducco-500g-detail Acesso em: 10 de mai de 2019.

DUARTE, Rodrigo. 2019. Entrevista em 01 de jun de 2019.

ENGEL, James F.; BLACKWELL, Roger D.; MINIARD, Paul W. Comportamento do consumidor. 8. ed. Rio de Janeiro: LTC Ed., c2000. xix, 641p.

FGV. Qual a faixa de renda familiar das classes? Disponível em: https://cps.fgv.br/qual-faixa-de-renda-familiar-das-classes Acesso em 14 de mai de 2019.

IBGE. Pesquisa Mensal do Comércio, 13 de fevereiro de 2019. Disponível em: $<$ https://biblioteca.ibge.gov.br/visualizacao/periodicos/230/pmc_2018_dez.pdf> Acesso em 6 de abril de 2019.

KELLER, K.L. e MACHADO, M. Gestão estratégica de marcas. São Paulo: Pearson Prentice Hall, 2006.

LEVY, Michael; WEITZ, Barton A. Administração de varejo. São Paulo: Atlas, 2000. $695 \mathrm{p}$.

MEIO E MENSAGEM, Mundo verde amplia itens de marca própria. Disponível em: $\quad$ https://www.meioemensagem.com.br/home/ultimasnoticias/2018/08/20/mundo-verde-amplia-itens-de-marca-propria.html Acesso em 10 de mai de 2019.

NIELSEN, Flávia A. G.; SÁ, Adriano C.; cap 8 in - ANGELO, Claudio Felisoni de; NIELSEN, Flávia Angeli Ghisi; FOUTO, Nuno M. Martins Dias. Manual do varejo 
no Brasil. São Paulo: Saint Paul, 2012. 542 p.

Nielsen. MARCA PRÓPRIA TRAZ DESTAQUES EM BÁSICOS E PREMIUM, MESMO EM UM CENÁRIO DE RECESSÃO. 12 de julho de 2017. Disponível em: $\quad<$ https://www.nielsen.com/br/pt/insights/news/2017/Marca-propria-trazdestaques-em-basicos-e-premium-mesmo-em-um-cenario-de-recessao.html> Acesso em: 02 de out de 2018.

OLIVEIRA, Roberto Nascimento Azevedo de. - 2. Ed. Atual. Gestão Estratégica de Marcas próprias. Rio de Janeiro: Brasport, 2008.

PARENTE, Juracy. Varejo no Brasil: gestão e estratégia. São Paulo: Atlas, 2007. 388 p.

PETER, J. Paul; OLSON, Jerry C. Comportamento do consumidor e estratégia de marketing. 8.ed. São Paulo: Mc Graw-Hill,, c2009. xx, 555 p.

PEREIRA, Inês. Marcas de Supermercado. Revista de Administração de Empresas, v. 41, no 1, p. 16-27, 2001.

SOBRAL, Filipe; PECl, Alketa. Administração: teoria e prática no contexto brasileiro. São Paulo: Pearson Prentice Hall, 2008. xiii, 398 p.

SBVC. Estudo revela importante papel do varejo na economia brasileira. 29 de novembro de 2018. Disponível em: <http://sbvc.com.br/estudo-papel-varejo2018/> Acesso em 6 de abr de 2019.

TAEQ. Grupo Pão de Açúcar. Disponível em: $<$ https://m.facebook.com/taeqoficial/photos/a.170513719630494/70<7135659301628/?ty $\mathrm{pe}=3 \&$ source $=54>$ Acesso em: 19 de abr de 2019 .

TAVARES, Mauro Calixta. Gestão de marcas: construindo marcas de valor. São Paulo: HARBRA, 2008. xiv, 432 p.

TYBOUT, Alice M.; CALKINS, Tim.; Branding Gestão de Marcas. São Paulo: Saraiva, 2018.

VERGARA, Sylvia Constant. Projetos e relatórios de pesquisa em administração. 3. ed. São Paulo: Atlas, 2000. 92 p. 


\section{Apêndice 1 - Questionário}

Gostaria de alguns minutos da sua atenção para responder o questionário abaixo, com o intuito de realizar uma pesquisa acadêmica.

1) Quanto você pagaria pelo panettone/chocottone Bauducco?

$\mathrm{R} \$$

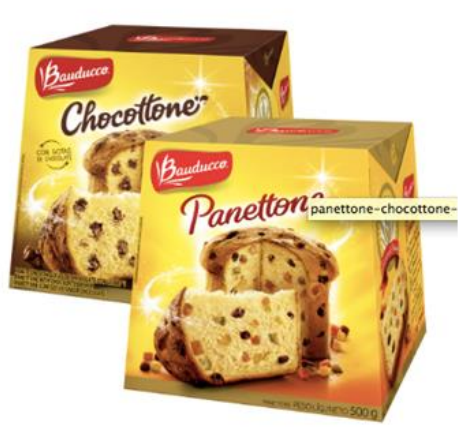

2) Qual a probabilidade de comprá-lo?

( ) Com certeza compraria

( ) Quase com certeza compraria

( ) Muito provável que compre

( ) Provável que compre

( ) Boa probabilidade de que compre

( ) Razoável probabilidade de que compre

( ) Alguma probabilidade de que compre

( ) Pouca probabilidade de que compre

( ) Pouquíssima probabilidade de que compre

( ) Insignificante probabilidade de que compre

( ) Nenhuma chance de comprar 
3) Agora, quanto você pagaria pelo panettone/chocottone Casa do Biscoito?

$\mathrm{R} \$$

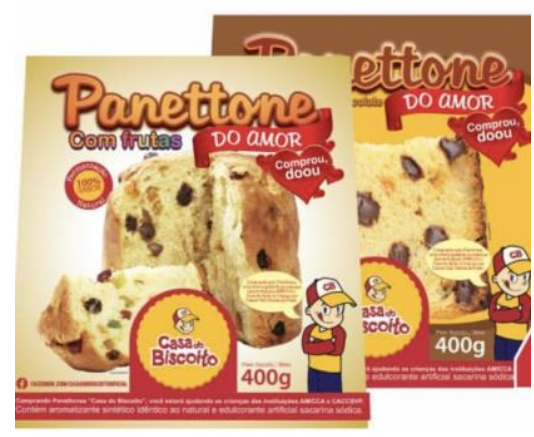

4) Qual a probabilidade de comprá-lo?
( ) Com certeza compraria
( ) Quase com certeza compraria
( ) Muito provável que compre
( ) Provável que compre
( ) Boa probabilidade de que compre
( ) Razoável probabilidade de que compre
( ) Alguma probabilidade de que compre
( ) Pouca probabilidade de que compre
( ) Pouquíssima probabilidade de que compre
( ) Insignificante probabilidade de que compre
( ) Nenhuma chance de comprar

5) Em relação ao salgadinho "Torcida", quanto pagaria por ele?

$\mathrm{R} \$$

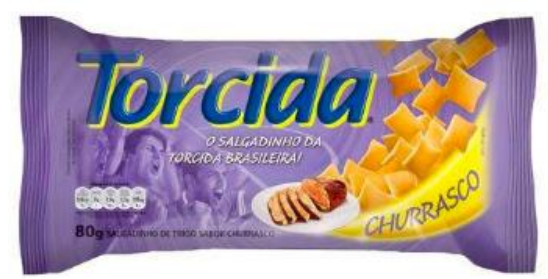


6) Qual a probabilidade de comprá-lo?

( ) Com certeza compraria

( ) Quase com certeza compraria

( ) Muito provável que compre

( ) Provável que compre

( ) Boa probabilidade de que compre

( ) Razoável probabilidade de que compre

( ) Alguma probabilidade de que compre

( ) Pouca probabilidade de que compre

( ) Pouquíssima probabilidade de que compre

( ) Insignificante probabilidade de que compre

( ) Nenhuma chance de comprar

7) Agora, em relação ao salgadinho "Casa do Biscoito", quanto pagaria por ele?

$\mathrm{R} \$$

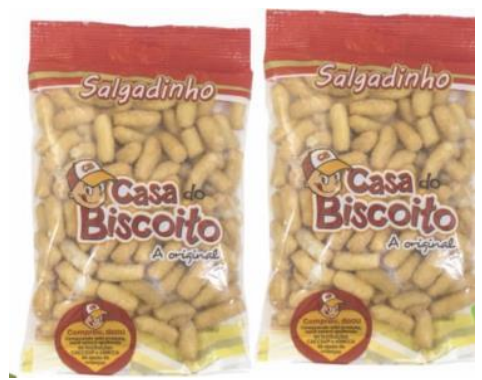

8) Qual a probabilidade de comprá-lo?

( ) Com certeza compraria

( ) Quase com certeza compraria

( ) Muito provável que compre

( ) Provável que compre

( ) Boa probabilidade de que compre

( ) Razoável probabilidade de que compre

( ) Alguma probabilidade de que compre

( ) Pouca probabilidade de que compre

( ) Pouquíssima probabilidade de que compre 

( ) Insignificante probabilidade de que compre
( ) Nenhuma chance de comprar

9) Com que frequência costuma comprar produtos de Marca Própria em geral, seja de um supermercado ou de outro lugar? (Marca Própria marcas concebidas e vendidas com exclusividade por varejistas ou atacadistas. Ex. Arroz Carrefour)
( ) Nunca
( ) $1 \times$ no mês
( ) 2x no mês
( ) $3 x$ no mês
( ) 4x no mês ou mais

10) Em uma escala de 1 a 5 , onde 5 é muito e 1 é pouco, como classifica a qualidade desses produtos de um modo geral?

( ) 1 ( ) 2 ( ) 3 ( ) 4 ( ) 5

11) Quais os principais fatores que o influenciam a adquirir um produto de Marca Própria? Neste, poderá marcar mais de um.
( ) Preço
( ) Qualidade
( ) Custo/Benefício
( ) Confiança na Marca
( ) Comodidade
( ) Não compro
( ) Outros

12) Como costuma chegar até um produto de Marca Própria pela primeira vez?
( ) Degustação
( ) Visibilidade na loja
( ) Indicação
( ) Não compro
( ) Outro

13) Em relação aos produtos de Marca Própria da Casa do Biscoito, você: 
( ) Não conhece

( ) Conhece, mas nunca comprou

( ) Já comprou, mas não compra mais

( ) Compra pelo menos $1 x$ no mês

( ) Compra pelo menos 2x no mês

( ) Compra pelo menos 3x no mês

( ) Compra pelo menos $4 x$ no mês ou mais

14) Com que frequência costuma comprar quaisquer produtos na Casa do Biscoito?

( ) Nunca

( ) $1 \times$ no mês

( ) 2x no mês

( ) 3x no mês

( ) 4x no mês ou mais

15) Em uma escala de 1 a 5, onde 5 é muito bom e 1 é ruim, o quanto está satisfeito com os itens abaixo em relação a Casa do Biscoito (A opção "não opino" é para os que não tiveram contato o suficiente para classificar o item):

\begin{tabular}{|l|l|l|l|l|l|l|}
\hline & 1 & 2 & 3 & 4 & 5 & Não opino \\
\hline Preço & & & & & & \\
\hline Atendimento & & & & & & \\
\hline Qualidade & & & & & & \\
\hline Variedade dos Produtos & & & & & & \\
\hline $\begin{array}{l}\text { Facilidade de encontrar os } \\
\text { produtos }\end{array}$ & & & & & & \\
\hline Localização das Lojas & & & & & & \\
\hline Produtos de Marca Própria & & & & & & \\
\hline
\end{tabular}

\section{Sobre o consumidor}

16) Idade?
( ) Menor que 18 anos
( ) $18-24$ anos
( ) $25-31$ anos
( ) $32-38$ anos
( ) $39-45$ anos 

( ) $46-51$ anos
( ) Maior que 51 anos

17) Sexo?

( ) Feminino

( ) Masculino

18) Escolaridade?

( ) Ensino Fundamental Incompleto

( ) Ensino Fundamental Completo

( ) Ensino Médio Incompleto

( ) Ensino Médio Completo

( ) Ensino Superior Incompleto

( ) Ensino Superior Completo

( ) Pós Graduação Incompleta

( ) Pós Graduação Completa

19) Renda?

( ) Até $\mathrm{R} \$ 1.254,00$

( ) De $R \$ 1.255,00$ até $R \$ 2004,00$

( ) De $R \$ 2005,00$ até $R \$ 8.640,00$

( ) De $R \$ 8.641,00$ até $R \$ 11.261,00$

( ) Acima de $R \$ 11.262,00$

20) Com quem mora atualmente?
( ) Com os pais
( ) Esposo(a)
( ) Filho(s)
( ) Esposo(a) e Filho(s)
( ) Amigo(s)
( ) Sozinho
( ) Outros

21) Onde reside?
( ) Zona Oeste
( ) Zona Sul
( ) Zona Norte 

( ) Região Metropolitana
( ) Fora do estado do Rio de Janeiro

22) Profissão?
( ) Estudante
( ) Funcionário de Empresa Pública
( ) Funcionário de Empresa Privada
( ) Autônomo
( ) Empresário
( ) Não estou trabalhando no momento 